\title{
UNIVERSITYOF
}

FORWARD

THINKING

WESTMINSTER用

WestminsterResearch

http://www.westminster.ac.uk/westminsterresearch

\section{The Legality of Closure on Land and Safe Passage between the} Gaza Strip and the West Bank

\section{Longobardo, $\mathbf{M}$.}

This journal article has been accepted for publication and will appear in a revised form, subsequent to peer review and/or editorial input by Cambridge University Press in the Asian Journal of International Law. This version is free to view and download for private research and study only. Not for re-distribution, re-sale or use in derivative works.

(C) Cambridge University Press, 2020

The final definitive version in the online edition of the journal article at Cambridge Journals Online will be available at:

https://doi.org/10.1017/S2044251320000272

The WestminsterResearch online digital archive at the University of Westminster aims to make the research output of the University available to a wider audience. Copyright and Moral Rights remain with the authors and/or copyright owners. 
The Legality of Closure on Land and Safe Passage between the Gaza Strip and the West Bank

\author{
Dr Marco LONGOBARDO* \\ University of Westminster, London, UK \\ m.longobardo1@westminster.ac.uk
}

\begin{abstract}
This article explores the legality of the land closure imposed upon the Gaza Strip by Israel. After having considered the area under occupation, the article argues that the legality of the closure must be determined under international humanitarian law, international human rights law, the principle of self-determination of peoples, and the IsraeliPalestinian agreements. In light of these rules, the arbitrary closure of the Gaza Strip should be considered illegal because it breaches the unity between the Gaza Strip and the West Bank and because it violates the freedom of movement of the local population. Moreover, the closure breaches the relevant rules pertaining to the transit of goods in occupied territory. This article concludes that most of the violations caused by the closure affect peremptory rules which produce obligations erga omnes, so that any state in the international community is entitled to react under the law of state responsibility.
\end{abstract}

\footnotetext{
* Lecturer in International Law. Although some of the research for this article was conducted in the framework of a project supported by the Norwegian Refugee Council, this paper reflects my views only. Thanks to Itay Epshtain for having discussed these issues with me. All internet references last accessed on 31 July 2020, when the manuscript was finalized. The usual disclaimers apply.
} 
This article aims at exploring the legality of the land closure imposed by Israel on the Gaza Strip, with particular reference to the freedom of movement of the Palestinians and of goods between the Gaza Strip and the West Bank. Access to the Gaza Strip is currently restricted by both an air and maritime blockade and a land closure. Whereas the legality of the maritime blockade has been addressed by a number of UN bodies and states' missions, ${ }^{1}$ receiving intense coverage by international scholarship as well, ${ }^{2}$ the legality of the land closure has been scrutinized only in a relatively cursory way. ${ }^{3}$ This article fills this void, exploring the legality of the land closure under a variety of applicable different international law rules.

After 2007, after Hamas' victory in the elections in Gaza, Israel imposed a closure on the borders of the Gaza Strip. ${ }^{4}$ This closure was followed by a naval blockade established in $2009 .{ }^{5}$ Since then, the international community and international civil society have become increasingly concerned over the humanitarian situation of the Gaza Strip. Israel, on the basis of alleged security reasons, has imposed restrictions on the goods that can enter and exit the area, reducing dramatically the freedom of movement of persons from and into that territory. As a result, for a resident of the Gaza Strip today, it is not only very difficult to exit the area to go abroad, but also movement between the Gaza Strip and the West Bank is seriously impaired. Since the specific measures adopted by Israel vary frequently, this article refers to the policy document published by the Coordination of Government

\footnotetext{
${ }^{1}$ Report of the International Fact-Finding Mission to Investigate Violations of International Law, Including International Humanitarian and Human Rights Law, Resulting from the Attacks on the Flotilla of Ships Carrying Humanitarian Assistance, UN Doc. A/HRC/15/21 (2010); Israel, "The Public Commission to Examine the Maritime Incident of 31 May 2010, The Turkel Commission Report" (23 January 2011), online: Jewish Virtual Library <www.jewishvirtuallibrary.org/jsource/Society_\&_Culture/TurkelCommission.pdf>; Turkish National Commission of Inquiry, "Report on the Israeli Attack on the Humanitarian Aid Convoy to Gaza on 31 May 2010" (11 February 2011), online: Turkish Government <www.mfa.gov.tr/data/Turkish\%20Report\%20Final\%20-\%20UN\%20Copy.pdf>; Report of the Secretary-General's Panel of Inquiry on the 31 May 2010 Flotilla Incident (July 2011), online: UN <www.un.org/News/dh/infocus/middle_east/Gaza_Flotilla_Panel_Report.pdf>.

${ }^{2}$ On this topic (and with some discussion of the land closure in connection to the blockade), see, e.g., Andrew SANGER, "The Contemporary Law of Blockade and the Gaza Freedom Flotilla" (2010) 13 Yearbook of International Humanitarian Law 397; Russel BUCHAN, "The International Law of Naval Blockade and Israel's Interception of the Mavi Marmara" (2011) 58 Netherlands International Law Review 209; Douglas GUILFOYLE, "The Mavi Marmara Incident and Blockade in Armed Conflict" (2011) 81 British Yearbook of International Law 171; Noura ERAKAT, "It's Not Wrong, It's Illegal: Situating the Gaza Blockade between International Law and the UN Response" (2011) 11 UCLA Journal of Islamic \& Near Eastern Law 37.

${ }^{3}$ For two exceptions, see Justus Reid WINER and Diane MORTIMER, "Legal Implications of "Safe Passage": Reconciling a Viable Palestinian State with Israel's Security Requirements" (2007) 22 Connecticut Journal of International Law 233; Michal LUFT, "Living in a Legal Vacuum: The Case of Israel's Legal Position and Policy towards Gaza Residents" (2018) 51 Israel Law Review 193.

4 Israel, Behind the Headlines: Israel Designates Gaza a "Hostile Territory" (24 September 2007), online: Israeli Government <mfa.gov.il/MFA/ForeignPolicy/Issues/Pages/Gaza\%20designated\%20a\%20\%E2\%80\%9CHostile\%20Territory\%E2\% 80\%9D\%2024-Sep-2007.aspx>.

5 Turkel Report, supra note 1 at para. 1.
} 
Activities in the Territories (COGAT) in August 2019, which governs the transit of persons and goods to and from the area since then. ${ }^{6}$

This article analyses the legality of closure of land and safe passage between the Gaza Strip and the West Bank, taking into account international humanitarian law, international human rights law, and other applicable rules of public international law. The article only addresses the legality of the closure itself, rather than all the legal consequences arising from the occupation and closure. The article addresses the relevant issues only from the standpoint of international law, even though the situation of the Gaza Strip could be analyzed from different non-legal perspectives as well. The research contributes to the existing scholarship by offering one of the first analysis of the freedom of movement in occupying territory, which could be useful to scrutinize the legality of the actions of occupying powers even outside the Occupied Palestinian Territory (OPT).

The arguments herein are presented irrespective of any consideration as to whether Palestine is a state or not under international law, ${ }^{7}$ since this issue is not decisive to determine the legality of the closure. Accordingly, the questions analyzed below under the principle of self-determination of peoples, a fortiori, could be analyzed under the rules pertaining to state sovereignty. Similarly, the article does not challenge the Palestinian entitlement to join certain multilateral treaties if depositories have accepted the relevant applications, ${ }^{8}$ but rather, considers them as binding irrespective of any final determination on Palestinian statehood. Finally, it is entirely irrelevant to debate whether the Israeli-Palestine Liberation Organization (PLO) agreements should be considered binding only upon

\footnotetext{
${ }^{6}$ Coordination of Government Activities in the Territories (COGAT), Unclassified Status of Authorizations for the Entry of Palestinians into Israel, their Passage between Judea and Samaria and the Gaza Strip and their Travel Abroad (updated as of 27 August 2019) (unofficial English translation), online: Gisha <www.gisha.org/UserFiles/File/LegalDocuments/procedures/general/50en.pdf>.

${ }^{7}$ For different views on the Palestinian statehood, see John QUIGLEY, The Statehood of Palestine: International Law in the Middle East Conflict (Cambridge: Cambridge University Press, 2010); Jean SALMON, 'La qualité d'Etat de la Palestine" (2012) 45 Revue belge de droit international 13; Marco LONGOBARDO, "Lo Stato di Palestina: emersione fattuale e autodeterminazione dei popoli prima e dopo il riconoscimento dello status di Stato non membro delle Nazioni Unite" in Marcella DISTEFANO, ed., Il principio di autodeterminazione dei popoli alla prova del nuovo millennio (Padua: CEDAM, 2014), 9; Thierry GARCIA, ed., La Palestine: d'un etat non membre de l'organisation des Nations Unies a un etat souverain? (Paris: Pedone, 2015); Djamchid MOMTAZ, "La controverse sur le statut de la Palestine" in Rüdiger WOLFRUM et al., eds., Contemporary Developments in International Law: Essays in Honour of Budislav Vukas (Leiden: Brill, 2016) 102; Shadi SAKRAN, The Legal Consequences of Limited Statehood: Palestine in Multilateral Frameworks (Abingdon: Routledge, 2019). See, also, Asian-African Legal Consultative Organization, A Study on the Statehood of Palestine under International Law (New Delhi: AALCO, 2013).

${ }^{8}$ On the Palestinian accession to these conventions, see Marco LONGOBARDO, "La recente adesione palestinese alle convenzioni di diritto umanitario e ai principali trattati a tutela dei diritti dell'uomo" (2014) 1 Ordine internazionale e diritti umani 771; Shadi SAKRAN and HAYASHI Mika, "Palestine's Accession to Multilateral Treaties: Effective Circumvention of the Statehood Question and its Consequences" (2017) 25 Journal of International Cooperation Studies 81.
} 
PLO as a movement of national liberation or, rather, also on the State of Palestine as its alleged successor. ${ }^{9}$ The use of the expression "Palestine" here should be interpreted accordingly, following the practice of the UN. ${ }^{10}$

The article is organized as follows. Section I explores the status of the Gaza Strip as an occupied territory, from which it is possible to identify the relevant applicable legal framework (Section II). Section III questions the legality of the closure in its entirety under the law of occupation. Section IV demonstrates that the West Bank and the Gaza Strip are a single territorial unity and that safe passage between the two areas is demanded by international law as a condition of maintaining said unity. Section V explores the freedom of movement of peoples between the Gaza Strip and the West Bank in light of applicable rules of international law protecting individual rights, whereas Section VI describes the legal framework applicable to the movement of goods. Section VII explores the remedies that can be adopted in relation to the violations of international law resulting from the land closure of the Gaza Strip. The article concludes that, although international law allows Israel to limit the freedom of movement of specific goods and persons on the basis of security grounds, the overall closure of the Gaza Strip is unlawful because it targets the entire population of the Gaza Strip.

\section{THE GAZA STRIP AS OCCUPIED TERRITORY}

In order to investigate the applicable legal framework and the legality of the closure of the Gaza Strip, this article first needs to assess whether the area is still under occupation. This article offers only a brief analysis of this complex issue that continues to attract significant attention in international scholarship. ${ }^{11}$

\footnotetext{
${ }^{9}$ On these agreements, see below Section 3.

${ }^{10}$ See A/RES/43/177 (15 December 1988) para 3.

${ }^{11}$ For a variety of opinions on this issue, see, e.g., Alain BOCKEL, "Le retrait israélien de Gaza et ses conséquences sur le droit international" (2005) 51 Annuaire français de droit international 16; Yuval SHANY, "Faraway, So Close: The Legal Status of Gaza after Israel's Disengagement" (2005) 8 Yearbook of International Humanitarian Law 369; Iain SCOBBIE, “An Intimate Disengagement: Israel's Withdrawal from Gaza, the Law of Occupation and of SelfDetermination" (2004-2005) 11 Yearbook of Islamic and Middle Eastern Law 3; SD Dikker HUPKES, What Constitutes Occupation? Israel as the Occupying Power in the Gaza Strip after the Disengangement (Leiden: EM Meijers Instituut, 2007); Shane DARCY and John REYNOLDS, "An Enduring Occupation: The Status of the Gaza Strip from the Perspective of International Humanitarian Law" (2010) 15 Journal of Conflict \& Security Law 211; Konstantinos MASTORODIMOS, "How and When Do Military Occupations End?" (2009) 21 Sri Lanka Journal of International Law 109; Solon SOLOMON, “Occupied or Not: The Question of Gaza's Legal Status after the Israeli Disengagement” (2011) 19 Cardozo Journal of International and Comparative Law 59; Eyal BENVENISTI, The International Law of Occupation, 2nd ed. (Oxford: Oxford University Press, 2012), 211-212; Hanne CUYCKENS, "Is Israel Still an Occupying Power in Gaza?" (2016) 63 Netherlands International Law Review 275.
} 
First comprised in the defunct British Mandate and subsequently occupied by Egypt in 1949, the Gaza Strip has been under Israeli occupation since 1967, when Israel gained control of the area during the Six-Day War. ${ }^{12}$ During the 1990s, Israel and the PLO negotiated a regime of Palestinian administration for some parts of the Occupied Palestinian Territory, which was detailed in a number of agreements never fully implemented, such as the the 1993 Declaration of Principles on Interim Self-Government Arrangements, ${ }^{13}$ the 1994 Agreement on Gaza Strip and Jericho Area, ${ }^{14}$ and the 1995 Israeli-Palestinian Interim Agreement. ${ }^{15}$ In 2005, Israel unilaterally decided to withdraw its military troops from the area, removing at the same time all the Israeli settlements, pursuant to the so-called Disengagement Plan. ${ }^{16}$ In 2007, following Hamas' victory in the elections in Gaza, Israel declared the Gaza Strip as "hostile territory," 17 upgrading its status to "enemy territory" in 2014. ${ }^{18}$ During the past decade, Israel has launched a number of largescale military operations in the Gaza Strip against Hamas and other armed groups, in response to the launch of mortars and rockets, ${ }^{19}$ whereas less intense violence - to be dealt with in the context of law enforcement operations - erupted in 2018 close to the perimeter fence between the Gaza Strip and Israel. ${ }^{20}$

After the Disengagement, the government of Israel has claimed that it is no longer occupying the Gaza Strip, so that the law of occupation does not bind Israeli action in the area. ${ }^{21}$ The Supreme Court of Israel concurred on the termination of the occupation, even though it affirmed that Israel maintains some post-occupation responsibilities. ${ }^{22}$ Conversely, most international institutions consider that the

12 See, generally, Peter MALANCZUK, "Israel: Status, Territory and Occupied Territories" in Rudolf BERNHARDT, ed., Encyclopedia of Public International Law (Amsterdam: North-Holland, 1990), 149; Yoram DINSTEIN, The International Law of Belligerent Occupation, $2^{\text {nd }}$ ed. (Cambridge: Cambridge University Press, 2019), 17.

1313 September 1993, text in 32 I.L.M. 1525.

144 May 1994, text in 33 I.L.M. 622.

1528 September 1995, text in 37 I.L.M. 557.

16 Israel, "Israel's Disengagement Plan: Renewing the Peace Process" (20 April 2005), online: Israeli Government $<$ mfa.gov.il/mfa/foreignpolicy/peace/guide/pages/israels $\% 20$ disengagement $\% 20$ plan-

\%20renewing\%20the\%20peace\%20process\%20apr\%202005.aspx >.

17 Israel, "Behind the Headlines: Israel Designates Gaza a 'Hostile Territory"” (24 September 2007), online: Israeli Government

<mfa.gov.il/MFA/ForeignPolicy/Issues/Pages/Gaza\%20designated\%20a\%20\%E2\%80\%9CHostile\%20Territory\%E2\% 80\%9D\%2024-Sep-2007.aspx>.

18 Israel, "The Torts Order (State Liability) (Declaration on Enemy Territory-Gaza Strip)" (7 October 2014) (unofficial English translation), online: Hamoked <www.hamoked.org/files/2015/1159680_eng.pdf>.

19 Operation Cast Lead (December 2008-January 2009); Operation Pillar of Clouds (November 2012); Operation Protective Edge (June-July 2014).

20 See Report of the Detailed Findings of the Independent International Commission of Inquiry on the Protests in the Occupied Palestinian Territory, U.N. Doc. A/HRC/40/CRP.2 (2019).

21 See, e.g., UN Doc. A/60/PV.5 (2005), 46.

22 HCJ 9132/07, Al-Bassiouni Ahmed et al v. Prime Minister et al. (27 January 2008), para. 12, (unofficial English translation), online: Cardozo University <https://versa.cardozo.yu.edu/sites/default/files/upload/opinions/Ahmed\%20v.\%20Prime\%20Minister.pdf>. 
Gaza Strip is still under Israeli occupation since Israel maintains total control over the maritime territory of the area, its airspace, its borders (with the exception of the Rafah crossing on the border with Egypt), and its vital supplies. ${ }^{23}$

To solve the conundrum of whether the Gaza Strip is still under occupation, one should note that international humanitarian law considers that a territory is under occupation if it is placed under the actual authority of a hostile force, pursuant to Article 42 of the 1907 Hague Regulations (HR), which corresponds to international customary law. ${ }^{24}$ The relevant test is factual in nature, ${ }^{25}$ i.e., it is immaterial whether an occupying power considers itself bound by the law of occupation. ${ }^{26}$ There is nothing in Article 42 of the HR about the actual presence of troops in occupied territory as a necessary element to establish an occupation, but rather, international case law considered the physical deployment of troops to be one of the elements from which it is possible to conclude that an area is under occupation. ${ }^{27}$ In any case, what it is crucial in relation to the Gaza Strip is that the actual physical presence of enemy troops did establish the occupation in 1967, so that even supporters of the idea that an occupation can be established only with boots on the ground should concede that the test was met. Conversely, there is nothing in the law of occupation that suggests that the presence of troops is a conditio sine qua non for the maintenance of an occupation after actual authority is established, ${ }^{28}$ especially when the occupying power exercise the same actual authority through other

23 UN Doc. S/RES/1860 (2009), preamble; UN Doc. A/RES/64/94 (2010), para. 4; UN Doc, A/HRC/12/48 (2009), paras. 273-79; A/HRC/15/21 (2010), paras. 63-66; UN Doc. A/HRC/29/CRP.4 (2015), paras. 26-31; UN Doc. A/HRC/40/CRP.2 (2019), paras. 61-67; Office of the Prosecutor of the ICC, "Situation on Registered Vessels of Comoros, Greece and Cambodia: Article 53(1) Report" (6 November 2014), paras. 27-29; "Prosecution request pursuant to article 19(3) for a ruling on the Court's territorial jurisdiction in Palestine", ICC-01/18-12 (22 January 2020), para. 80; Peter MAURER (as president of the ICRC), "Challenges to International Humanitarian Law: Israel's Occupation Policy" (2012) 94 International Review of the Red Cross 1504 at 1506.

${ }^{24}$ See, e.g., Legal Consequences of the Construction of a Wall in the Occupied Palestinian Territory, Advisory Opinion, [2004] I.C.J. Rep. 136 at para. 79; Case Concerning Armed Activities on the Territory of the Congo (DRC v. Uganda), [2005] I.C.J. Rep. 168 at para. 172.

${ }^{25}$ See Tristan FERRARO, "Determining the Beginning and End of an Occupation under International Humanitarian Law" (2012) 94 International Review of the Red Cross 133 at 134-6.

${ }^{26}$ US Military Manual (Washington, DC: Department of Defence, 2016) section 11.2.1.

${ }^{27}$ Prosecutor v. Naletilić, Trial Chamber, Judgment of 31 March 2003, para. 217; Prosecutor v. Prlić et al., Appeals Chamber, Judgment of 29 November 2017, para. 320.

28 Tristan FERRARO, ed., Report on Expert Meeting, Occupation and Other Forms of Administration of Foreign Territory (Geneva: International Committee of the Red Cross, 2012), 17; Julia GRIGNON, "The Geneva Conventions and the End of Occupation" in Andrew CLAPHAM, Paola GAETA and Marco SASSÒLI, eds., The 1949 Geneva Conventions: A Commentary (Oxford: Oxford University Press, 2015), 1575, at 1594-1595; Tristan FERRARO and Lindsey CAMERON, "Article 2: Application of the Convention" in ICRC, Updated Commentary on the First Geneva Convention (Cambridge, Cambridge University Press, 2016), paras. 307-309. 
means. ${ }^{29}$ Indeed, under the law of occupation it is well-established that the occupying power does not need to control physically every square-meter of the occupied territory.

Accordingly, taking into account the ongoing Israeli control over significant portions of Gaza territory - namely the territorial waters and airspace ${ }^{30}$ - and in light of the control over Gaza borders, supplies, and population registry, the Disengagement did not terminate Israel's actual authority over the Gaza Strip, ${ }^{31}$ and as a result the law of occupation still applies. ${ }^{32}$ From a legal point of view, the Disengagement from the Gaza Strip must be considered as a redeployment of troops within an occupied territory comprising both the Gaza Strip and the West Bank. ${ }^{33}$ The different degree of authority exercised by Israel after the Disengagement is relevant as a factual element to be taken into account in relation to the Israeli capacity of exercising responsibilities under the law of occupation in relation to those obligations that require the occupying power to do everything in its power to reach a certain aim (positive obligations of conduct). ${ }^{34}$

As mentioned afore, the conclusion that the Gaza Strip is still under occupation is not shared by the Supreme Court of Israel, according to which the area is no longer occupied. ${ }^{35}$ However, the Supreme Court of Israel maintains that Israel is still bound by some rules embodied in the law of occupation. ${ }^{36}$ As argued by some Israeli scholars, this conclusion is legally absurd: the consideration that Israel is bound by the law of occupation can only derive from the fact that the Gaza Strip is under occupation. ${ }^{37}$ Likewise, the designation of the Gaza Strip as "hostile territory" and "enemy territory" under Israeli domestic law has no consequence in relation to the characterization of the area as

\footnotetext{
${ }^{29}$ For the opposite view, which unfortunately cannot be explored here in details, see Solomon, supra note 11; Eyal BENVENISTI, The International Law of Occupation, 2nd ed. (Oxford: Oxford University Press, 2012), 211-212; Cuyckens, supra note 11.

${ }^{30}$ On the interpretation of the notion of territory under the law of occupation, see generally Marco LONGOBARDO, "The Occupation of Maritime Territory under International Humanitarian Law” (2019) 95 International Law Studies 322.

31 See, e.g., Bockel, supra note 11 at 23; Carey JAMES, "Mere Words: The Enemy Entity Designation of the Gaza Strip" (2009) 32 Hastings International \& Comparative Law Review 643; Darcy and Reynolds, supra note 11 at 235; Grignon, supra note at 1593-1596; Eric DAVID, Principes de Droit des Conflits Armés, 6th ed. (Bruxelles: Bruylant, 2019), 699; Dinstein, supra note 12 at 297.

32 This is also the positions of those who consider that the Gaza Strip is no longer occupied under the traditional test embodied in art. 42 of the HR, but the law of occupation should apply following a functional approach (see, e.g., Aeyal GROSS, The Writing on the Wall: Rethinking the International Law of Occupation (Cambridge: Cambridge University Press, 2017), 213-214).

33 Ibid., at 298.

34 This view has been suggested by the EECC, Partial Award: Western Front, Aerial Bombardment and Related Claims - Eritrea's Claims 1, 3, 5, 9-13, 14, 21, 25 \& 26, 19 Dec 2005, XXVI RIAA 291, para 27. See also Luft, supra note 3 at 201.

${ }^{35}$ See Al-Bassiouni case, supra note 22 at para. 12. In support of this view, see Solomon, supra note 11.

${ }^{36} \mathrm{Ibid}$.

37 See, e.g., Yuval SHANY, “The Law Applicable to Non-Occupied Gaza: A Comment on Bassiouni v. The Prime Minister of Israel" (2009) 42 Israel Law Review 101 at 108; Dinstein, supra note 12 at 300-301.
} 
occupied territory. As mentioned above, under international humanitarian law it is irrelevant whether the occupying power acknowledges that an occupation exists. Moreover, by definition, the occupied territory is "hostile" and "enemy" territory, since occupation is a portion of an ongoing armed conflict. ${ }^{38}$ Accordingly, these definitions are devoid of any legal meaning and do not alter the conclusion that the Gaza Strip is under occupation.

It should be noted that the land closure and the blockade of the Gaza Strip, combined with the Disengagement Plan, have led some commentators to consider the situation of the Gaza Strip as that of a siege, ${ }^{39}$ whereas Israel has vocally rejected this proposition, preferring to refer to the situation as a closure. ${ }^{40}$ Labelling the situation of the Gaza Strip as a siege does not alter the characterization of the area as occupied territory. Under international humanitarian law, a siege "is a factual description of what is going on without any specific connotation." ${ }^{41}$ In other words, there is no legal regulation of sieges as such, but rather, the key issue is whether a specific situation that we call siege can comply with international law. ${ }^{42}$ Contrary to the allusions of some observers,${ }^{43}$ what is usually called siege is compatible with a situation of occupation if the siege occurs in a portion of territory from whence the occupying power has redeployed its troops. Sieges and blockades are methods of warfare and hostilities may occur in occupied territory without altering the situation of occupation, as affirmed by significant case law. ${ }^{44}$ In fact, the law of occupation embodies some references to hostilities in occupied territory, such as Article 49 of the GCIV (referring to "imperative military reasons") and Article 53 of the GCIV (referring to "military operations"). Accordingly, the resort to a method of warfare such as a blockade or a siege does not necessarily imply that the occupation is over, but

\footnotetext{
${ }^{38}$ See Marco LONGOBARDO, The Use of Armed Force in Occupied Territory (Cambridge: Cambridge University Press, 2018), 20-21. Indeed, the very Section III of the 1907 Hague Regulations (HR), which embodies rules applicable during an occupation, is labelled "Military authority over the territory of the hostile state" (Convention (IV) respecting the Laws and Customs of War on Land and its annex: Regulations concerning the Laws and Customs of War on Land, 205 CTS 277).

39 See, e.g., Shany, supra note 37; Gabriella VENTURINI, "L'operazione militare di Israele contro Gaza e il diritto internazionale umanitario" (2009) 3 Diritti umani e diritto umanitario 309 at 313.

40 Israel, "Behind the Headlines: The Myth of an Israeli Siege on Gaza" (17 August 2014), online: Israeli Government <mfa.gov.il/MFA/ForeignPolicy/Issues/Pages/The-myth-of-an-Israeli-siege-on-Gaza-17-Aug-2014.aspx>.

41 Françoise HAMPSON, “A Terminological Issue: What Is a Siege?” (2015) Colloquium 91 at 93.

42 See, generally, Emanuela-Chiara GILLARD, "Sieges, the Law and Protecting Civilians" (27 June 2019), online: Chatham House <www.chathamhouse.org/publication/sieges-law-and-PROTECTING-civilians>.

43 See, e.g., Hampson, supra note 41 at 93; Marco SASSÒLI, International Humanitarian Law: Rules, Controversies, and Solutions to Problems Arising in Warfare (Cheltenham: Edward Elgar, 2019), 306.

44 US Military Tribunal, Nuremberg, Willelm List et al. (19 February 1948), (1948) 9 L.R.T.W.C. 34 ay 56 ; Naletilić case, supra note 27 at para. 217; Prlić case, supra note 27 at para. 320.
} 
rather, when hostilities erupt in occupied territory the situation must be assessed on a case-by-case basis. $^{45}$

\section{THE APPLICABLE LEGAL FRAMEWORK}

To understand the legality of the closure on land of the Gaza Strip it is necessary to take into account a variety of applicable rules of public international law, both enshrined in treaties and developed in customary international law.

Since it is argued here that the Gaza Strip is under ongoing occupation, international humanitarian law and, in particular, the rules embodied in the HR and in the 1949 Four Geneva Conventions (GCs) ${ }^{46}$ apply. The rules contained in 1977 First Additional Protocol (API) ${ }^{47}$ apply as long as they reflect customary international $\operatorname{law}^{48}$ as Israel is not a party to the API. Following the opinion of the International Court of Justice (ICJ), ${ }^{49}$ of some UN bodies, ${ }^{50}$ of Israel, ${ }^{51}$ and of most scholars,${ }^{52}$ the law on international armed conflict is considered to be the correct legal framework rather than the law of non-international armed conflict. This is a consequence of the fact that, de lege lata, an occupation can be established only during an international armed conflict. ${ }^{53}$

Additionally, it is necessary to take into account various rules of international human rights law, particularly some of the rights enshrined in the 1966 UN International Covenant on Civil and Political

\footnotetext{
${ }^{45}$ For more on this, see Longobardo, supra note 38 at 198-204.

${ }^{46}$ Geneva Convention Relative to the Protection of Civilian Persons in Time of War (Fourth Geneva Convention) (12 August 1949) 75 U.N.T.S. 287.

47 Protocol Additional to the Geneva Conventions of 12 August 1949, and relating to the Protection of Victims of International Armed Conflicts (Protocol I) (8 June 1977) 1125 U.N.T.S. 3.

48 See the authoritative collection of customary rules in Jean-Marie HENCKAERTS and Louise DOSWALD-BECK, eds., Customary International Humanitarian Law, vol. I (Cambridge: Cambridge University Press, 2005).

49 Wall opinion, supra note 24 at para. 124 (discussing the application of art. 23(g) of the HR).

50 UN Doc. A/HRC/12/48 (2009), para. 77; UN Doc. A/HRC/15/21 (2010), paras. 62-66; Report of the SecretaryGeneral's Panel, supra note 1 at para. 73.

51 HCJ 769/02, Public Committee against Torture in Israel v Israel, 14 Dec 2006, para 18, unofficial trans in (2007) 46 I.L.M. 375; Al-Bassiouni case, supra note 22 at paras. 12-15; HCJ 201/09, Physicians for Human Rights v Prime Minister (19 January 2009), para. 14 (unofficial English translation), online: EYLON <elyon1.court.gov.il/files_eng/09/010/002/n07/09002010.n07.pdf>; The Turkel Commission, supra note 1 at paras. 41 and 44.

52 Antonio CASSESE, International Law, $2^{\text {nd }}$ ed. (Oxford: Oxford University Press, 2005), 420; Dapo AKANDE, "Classification of Armed Conflicts: Relevant Legal Concepts" in Elizabeth WILMSHURST, ed., International Law and the Classification of Conflicts (Oxford: Oxford University Press, 2012), 32 at 47-48; Robert KOLB and Sylvain VITÉ, Le droit de l'occupation militaire (Bruxelles: Bruylant, 2009), 352; Kenneth WATKIN, "Use of Force during Occupation: Law Enforcement and Conduct of Hostilities" (2012) 94 International Review of the Red Cross 267 at 293 ; Noam ZAMIR, Classification of Conflicts in International Humanitarian Law (Cheltenham: Edward Elgar, 2017), 166; Longobardo, supra note 38 at 226-29.

${ }^{53}$ See US Supreme Court, Ford v. Surget, (1878) 97 U.S. 594 at 614; SCSL, Prosecutor v. Sesay et al., Judgment of 2 March 2009, paras. 982-988. See also US Military Manual, supra note 26 at section 11.1.3.3.
} 
Rights (ICCPR) ${ }^{54}$ and the 1966 UN International Covenant on Economic, Social and Cultural Rights (ICESCR). ${ }^{55}$ As it is well-known, the ICJ, in accordance with human rights regional courts and UN monitoring mechanisms, has affirmed on a number of occasions that international human rights law applies in situations of armed conflict and belligerent occupations, even when a state acts outside its territory. ${ }^{56}$ Accordingly, the occupying power must act in compliance with its international human rights law obligations when acting in the occupied territory, ${ }^{57}$ while respecting at the same time international humanitarian law. International case law demonstrates that the two sets of rules should be interpreted in light of one another to avoid, through interpretation, any possible normative conflict. ${ }^{58}$ For instance, the ICJ in the Nuclear Weapons opinion, under the label of lex specialis, applied international humanitarian law to interpret international human rights provisions applicable in armed conflict. ${ }^{59}$ This interpretive technique is possible thanks to the application of the rule codified in Article 31(3)(c) of the 1969 Vienna Convention on the Law of Treaties (VCLT), ${ }^{60}$ according to which " $[\mathrm{t}]$ here shall be taken into account, together with the context: ... any relevant rules of international law applicable in the relations between the parties." ${ }^{1}$

The fact that Hamas administers Gaza should be taken into account in assessing Israeli compliance with positive obligations under international human rights law, especially in the field of socioeconomic rights. The substantive obligations of international human rights law, which applies as a whole because Israel is an occupying power, should be determined taking into account the existence and the role of the Palestinian administration. ${ }^{62}$ This is particularly relevant for negative obligations embodied in international human rights conventions, which are not linked to Hamas's role in the Gaza

\footnotetext{
54 Text in 999 U.N.T.S. 171.

55 Text in 993 U.N.T.S. 3.

56 See Legality of the Threat or Use of Nuclear Weapons, Advisory Opinion, [1996] I.C.J. Rep. 226 at para. 25 ; Wall opinion, supra note 24 at para. 106; DRC v. Uganda case, supra note 24 at para. 216.

${ }^{57}$ On this topic, see, e.g., Eyal BENVENISTI, "The Applicability of Human Rights Conventions to Israel and to the Occupied Territories" (1992) 26 Israel Law Review 24; Orna BEN-NAFTALI and Yuval SHANY, "Living in Denial: The Application of Human Rights in the Occupied Territories" (2004) 37 Israel Law Review 17; Yutaka ARAITAKAHASHI, The Law of Occupation: Continuity and Change of International Humanitarian Law, and Its Interaction with International Human Rights Law (Leiden: Brill, 2009), 401-607; Noam LUBELL, "Human Rights Obligations in Military Occupation" (2012) 94 International Review of the Red Cross 317; Víctor Luis GUTIÉRREZ CASTILLO, "La aplicación extraterritorial del Derecho internacional de los derechos humanos en casos de ocupación beligerante" (2018) 36 Revista Electrónica de Estudios Internacionales 1.

${ }^{58}$ For more details, see the case law analysed by Longobardo, supra note 38 at 71-80.

${ }^{59}$ Nuclear Weapons opinion, supra note 56 at para. 25.

${ }^{60}$ Text in 1155 U.N.T.S. 331.

${ }^{61}$ See also ECtHR, Hassan v. the UK, Grand Chamber, Judgment of 16 September 2014, para. 100. For more on this interpretive criterion, see Richard GARDINER, Treaty Interpretation, 2nd ed. (Oxford: Oxford University Press, 2015), 298-333.

62 Lubell, supra note 57 at 323; Gross, supra note 32 at 214.
} 
Strip. As suggested by the ICJ, Israel "is under an obligation not to raise any obstacle to the exercise of [human] rights in those fields where competence has been transferred to Palestinian authorities." 63 As noted by a renowned expert, "while the context may modify the substance of the obligation, it does not remove it altogether; Israel is required not to actively raise obstacles with regard to the rights that the Palestinian Authority [and Hamas, mutatis mutandis] is administering." 64 The specific application of these rights, in light of these considerations, is discussed in a subsequent section. ${ }^{65}$

A variety of agreements concluded between Israel and the PLO in the 1990s specifically address legal issues that are relevant to determine the lawfulness of the Gaza Strip's closure. In particular, the 1993 Declaration of Principles on Interim Self-Government Arrangements, the 1995 IsraeliPalestinian Interim Agreement on the West Bank and the Gaza Strip, and the 1999 Protocol Concerning Safe Passage between the West Bank and the Gaza Strip ${ }^{66}$ all embody rules that must be taken into account. Since at the time of the conclusions of these agreements the PLO was recognized as a movement of national liberation, ${ }^{67}$ it was a subject of international law with treaty-making power in relation to the exercise of the principle of self-determination of peoples. ${ }^{68}$ It follows that the IsraelPLO agreements are binding treaties under international law ${ }^{69}$ and, accordingly, are sources of obligations both for the Palestinians and for Israel. ${ }^{70}$ Whether these treaties are still in force is a matter

${ }^{63}$ Wall opinion, supra note 24 at para. 112.

${ }^{64}$ Lubell, supra note 57 at 323-324.

${ }^{65}$ See infra, section V.B and V.C.

${ }^{66}$ Text available online, UN <unispal.un.org/UNISPAL.NSF/0/EEAF13D53D3503B285256F9B005B49E1>.

67 UN Doc. A/RES/3210 (XXIX) (1974). For more on this, see Anis F. KASSIM, "The Palestine Liberation Organization's Claim to Status: A Juridical Analysis under International Law” (1980) 9 Denver Journal of International Law and Policy 1; Quigley, supra note 7 at 133-148.

${ }^{68}$ Claude LAZARUS, "Le Statut International des Mouvements de Libération Nationale à l'Organisation des Nations Unies" (1974) 20 Annuaire français de droit international 173 at 198-9; Julio A. BARBERIS, "Nouvelles questions concernant la personnalité juridique international" (1983) 179 Recueil des Cours 145 at 259-64; Antonio CASSESE, Self-Determination of Peoples: A Legal Reappraisal (Cambridge: Cambridge University Press, 1995), 169; M. Angeles RUIZ COLOMÉ, Guerras civiles y guerras coloniales (Madrid: Eurolex, 1996), 41-86.

${ }^{69}$ This view is common in legal scholarship. See, e.g., Fabio MARCELLI, "Gli accordi fra Israele e OLP nel diritto internazionale" (1994) 77 Rivista di diritto internationale 430 at 464; Eyal BENVENISTI, "The Israeli-Palestinian Declaration of Principles: A Framework for Future Settlement" (1993) 4 European Journal of International Law 542 at 544-545; Peter MALANCZUK, "Some Basic Aspects of the Agreements between Israel and the PLO from the Perspective of International Law" (1996) 7 European Journal of International Law 485 at 488-492; Geoffrey R. WATSON, The Oslo Accords: International Law and the Israeli-Palestinian Peace Agreements (Oxford: Oxford University Press, 2000), 55-102; James CRAWFORD, "Israel (1948-1949) and Palestine (1988-1999): Two Studies in the Creation of States" in Guy S. GOODWIN-GILL and Stefan TALMON, eds., The Reality of International Law: Essays in Honour of Ian Brownlie (Oxford: Clarendon Press, 1999), 95 at 120-121. For an isolated contrary view, see Christine CHINKIN, "Normative Developments in the International Legal System" in Dinah SHELTON, ed., Commitment and Compliance: The Role of Non-Binding Norms in the International Legal System (Oxford: Oxford University Press, 2000), 21 at 26.

${ }^{70}$ Note that art. 3 of the VCLT clarifies that "[t]he fact that the present Convention does not apply to international agreements concluded between States [...] shall not affect [...] the legal force of such agreements". 
of debate: these agreements were meant to be interim accords that should have been replaced by a final agreement which, in fact, has never been adopted. However, it should be noted that these agreements have never been formally denounced, but rather, Israel relies on some of their provisions, ${ }^{71}$ while the numerous Palestinian threats to denounce them are evidence of the Palestinian belief that they are still binding. ${ }^{72}$ Moreover, the international community keeps considering them as binding: e.g., in 2016, the UNSC has stressed the need that the parties implement these agreements, ${ }^{73}$ emphasizing that the international rules applicable to the relations between Israel and Palestine includes "their previous agreements and obligations"; 74 the same request was advanced in 2019 by the UNGA. ${ }^{75}$ Indeed, the law of occupation allows belligerents to conclude such agreements, which must not alter the protection offered by the $\mathrm{GCIV}^{76}$ and must be interpreted coherently with the principle of self-determination of peoples. ${ }^{77}$ Accordingly, pending the occupation, due to the lack of any peace treaty concluded without coercion, protected persons continue to benefit of the protection offered by the GCIV, which cannot be altered by these agreements. ${ }^{78}$

Other rules of public international law complement the applicable legal framework. For instance, the principle of self-determination of peoples is taken into consideration since, as affirmed by the ICJ, the Palestinian people enjoys the right to self-determination. ${ }^{79}$ The customary content of this

\footnotetext{
${ }^{71}$ See, e.g., the Israeli communication to the depositary of the Statute of the International Criminal Court (Depository notification C.N.63.2015.TREATIES-XVIII.10 (Israel: Communication) (23 January 2015): “'Palestine' [...] lacks the legal capacity to join the aforesaid Statute under general international law, as well as under the terms of the Rome Statute and of bilateral Israeli-Palestinian agreements" (emphasis added); Israel, Office of the Attorney General, "The International Criminal Court's Lack of Jurisdiction over the So-Called 'Situation in Palestine"” (20 December 2019), online: Israeli

Government <https://mfa.gov.il/MFA/PressRoom/2019/Documents/ICCs\%20lack\%20of\%20jurisdiction\%20over\%20socalled $\% 20 \%$ E2\%80\%9Csituation\%20in\%20Palestine\%E2\%80\%9D\%20-\%20AG.pdf $>$, paras. 55-60.

72 See, e.g., "Palestinian leader Mahmoud Abbas ends security agreement with Israel and US", The Guardian (20 May 2020): Online: The Guardian <https://www.theguardian.com/world/2020/may/20/palestinian-leader-mahmoud-abbasends-security-agreement-with-israel-and-us >. Palestine acknowledged that this was obly a threat in its submission to the International Criminal Court (The State of Palestine's Response to the Pre-Trial Chamber's Order Requesting Additional Information, ICC-01/18-135 (04 June 2020), para. 13).

${ }^{73}$ UN Doc. S/RES/2334 (2016), preamble.

${ }^{74}$ Ibid., para. 7.

${ }^{75}$ UN Doc. A/RES/74/89 (2019), preamble.

${ }^{76}$ See arts. 7 and 47 of the GCIV.

77 Antonio CASSESE, “The Israel-PLO Agreement and Self-Determination” (1993) 4 European Journal of International Law 564 at 568-569.

${ }^{78}$ See, extensively, John QUIGLEY, “The PLO-Israeli Interim Agreements and the Geneva Civilians Convention” in Stephen BOWEN, ed., Human Rights, Self-Determination and Political Change in the Palestinian Occupied Territories (Leiden: Kluwer Law, 1997), 25; Robert KOLB, "Etude sur l'occupation et sur l'article 47 de la IVeme Convention de Genève du 12 août 1949 relative à la protection des personnes civiles en temps de guerre: le degré d'intangibilité des droits en territoire occupé" (2002) 10 African Yearbook of International Law 267.

${ }^{79}$ Wall opinion, supra note 24 at para. 118. See, in general, Paul J. I. M. De WAART, Dynamics of Self-determination in Palestine: Protection of Peoples as a Human Right (Leiden: Brill, 1994); Victor KATTAN, From Coexistence to
} 
principle, which is enshrined also in Articles 1(2) and 55 of the UN Charter and in Common Article 1(1) to the 1966 Covenants, has been clarified and codified by the UN General Assembly in a number of resolutions, such as the 1970 Declaration on Principles of International Law concerning Friendly Relations and Co-operation among States, ${ }^{80}$ that, albeit non-binding, have normative character. ${ }^{81}$

Finally, although this article acknowledges the role of Israeli domestic law and the relentless judicial activity of the Supreme Court of Israel concerning the Gaza Strip, ${ }^{82}$ under Article 38(1)(d) of the ICJ Statute, domestic decisions and legislation are not sources of international law. ${ }^{83}$ Compliance with domestic law is not a justification for lack of observance of international obligations under Article 27 of the VCLT, and Articles 3 and 32 of the International Law Commission's (ILC) 2001 Draft Articles on Responsibility of States for Internationally Wrongful Acts (DARS) ${ }^{84}$ Accordingly, Israeli legislation and case law should be taken into account as state practice, which, assessed along with other states' practice, may contribute to emergence of customary international law ${ }^{85}$ and to the interpretation of treaty provisions over time. ${ }^{86}$ However, they are not sources of international law.

\section{THE LEGALITY OF THE CLOSURE IN ITS ENTIRETY}

Pursuant to Article 43 of the HR, the main duty of the occupying power is to restore and ensure, as far as possible, the public order and the civil life in occupied territory, without altering, unless absolutely prevented, the law in force in the occupied territory prior to the occupation. The implementation of these duties requires occupying powers to undertake both negative and positive actions. The expression "as far as possible" means that the occupying power must endeavour to do everything that is in its power to restore and ensure public order and civil life, but the provision is not

Conquest: International Law and the Origins of the Arab-Israeli Conflict, 1891-1949 (London: Pluto Press, 2009), 117145; Antonello TANCREDI, "Le droit a l'autodétermination du peuple Palestinien" in Garcia, ed., supra note 7 at 33. ${ }^{80}$ UN Doc. A/RES/2626 (1970).

81 Legal Consequences of the Separation of the Chagos Archipelago from Mauritius in 1965, Advisory Opinion (25 February 2019), para. 155, online: ICJ <www.icj-cij.org/files/case-related/169/169-20190225-01-00-EN.pdf>.

${ }^{8} \mathrm{See}$, in particular, the case law analysed by Luft, supra note 3. More generally, on the contribution of the Supreme Court of Israel, see David KRETZMER, The Occupation of Justice: The Supreme Court of Israel and the Occupied Territories (New York: State University of New York Press, 2002); Rouba AL-SALEM, Security, Rights and Law: The Israeli High Court of Justice and Israeli Settlements in the Occupied West Bank (Abingdon: Routledge, 2018).

83 See, on domestic decisions, Alain PELLET and Daniel MÜLLER, "Article 38" in Andreas ZIMMERMANN et al., eds., The Statute of the International Court of Justice: A Commentary, 3rd ed. (Oxford: Oxford University Press, 2019), 819 at 953; on domestic legislation, Case concerning certain German interests in Polish Upper Silesia (Germany v. Poland) (Merits), [1926] P.C.I.J. Rep. Series A - No. 7, 3 at 19.

${ }^{84}$ UN Doc. A/56/49(Vol. I)/Corr.4 (2001).

85 Jurisdictional Immunities of the State (Germany v. Italy: Greece intervening) [2012] I.C.J. Rep. 99 at para. 55; International Law Commission (ILC), Draft Conclusions on Identification of Customary International Law, UN Doc. A/73/10 (2018), Conclusion 6.2.

${ }^{86}$ Art. 31(3)(b) of the VCLT. 
violated if public order and civil life are disrupted notwithstanding the diligent conduct of the occupying power. ${ }^{87}$ International case law has considered the violation of this rule as a source of state responsibility. ${ }^{88}$

The land closure of the Gaza Strip in its entirety violates Article 43 of the HR for two reasons. First, the restrictions on movements of goods and persons have severely impaired the civil life of the Gaza Strip. "Civil life" regards the "whole social, commercial and economic life of the community", 89 and "a variety of aspects of civil life, such as the economy, society, education, welfare, health, [and] transport". ${ }^{90}$ As noted by the World Bank, the combined effect of the closure and the blockade is strangling the economy of the area. ${ }^{91}$ Moreover, the severe restrictions imposed on the movement of persons affect fields such as education, healthcare, and welfare. Israel is not acting diligently to comply with its duty to restore and ensure civil life, nor does it present any serious evidence that the closure is a last resort measure and that no other alternative is feasible.

It should be born in mind that that Hamas's role in administering the Gaza Strip may reduce the latitude of the actions that Israel can undertake under Article 43 of the HR, which burdens the occupying power to acts "as far as possible", and which should take into account the amount of authority actually exercised case by case. ${ }^{92}$ This argument is correct in relation to to some positive obligations pertaining to the duty to restore and ensure public order and the civil life: e.g., Israel cannot be considered responsible for not maintaining working healthcare or police systems in the Gaza Strip, since these governmental functions are exercised by Hamas. This conclusion is in line with the due diligence character of the duties embodied in Article 43 of the HR. However, the same provision embodies also negative duties, i.e., obligations not to interfere with public order and civil life: these negative duties are not governed by due diligence, but rather, are obligations of negative result, which are violated every time Israel interferes with public order and civil life in the occupied

\footnotetext{
${ }^{87}$ See HCJ 69/81, Abu Aita et al. v. Regional Commander of the Judea and Samaria Area et al. (5 April 1983), para. 50(c), (unofficial English translation), online: Hamoked <www.hamoked.org/files/2011/290_eng.pdf>; Marco SASSÒLI, "Legislation and Maintenance of Public Order and Civil Life by Occupying Powers" (2005) 16 European Journal of International Law 661 at 664-665.

88 UN Compensation Commission, Governing Council Decision no. 9 (6 March 1992), 109 I.L.R. 593, paras. 12-15; DRC v. Uganda case, supra note 24 at para. 250.

89 Germany, British Zone of Control, Control Commission, Court of Criminal Appeal, Grahame v. Director of Prosecutions, 14 I.L.R. 228 at 232.

90 HCJ 393/82, Jam'iat Iscan Al-Ma'almoun v IDF Commander, 25 July 1982, para. 18 (unofficial English translation), online: Hamoked <www.hamoked.org/Document.aspx?dID=160>.

91 World Bank, "Economic Monitoring Report to the Ad Hoc Liaison Committee" (27 September 2018), para. 33, online: World Bank <documents.worldbank.org/curated/en/413851537281565349/pdf/129986-REVISED-World-Bank-Sept2018-AHLC-Report-final.pdf>.

${ }^{92}$ See Luft, supra note 3 at 201.
} 
territory. ${ }^{93}$ Accordingly, the closure of the Gaza Strip infringes upon the duty not to interfere with public order and civil life in the occupied territory; in other words, allowing the movement of goods and persons from the Gaza Strip to the West Bank and vice versa does not require the exercise of governmental powers exercised in Gaza by Hamas, but rather, it only demands negative actions from Israel. ${ }^{94}$ Clearly, as discussed below, Israel maintain the right to adopt specific targeted measures to ensure that no harm to its security is caused by this abstention of interference. ${ }^{95}$

Furthermore, the law of occupation bans collective punishment under Article 50 of the HR, according to which "no general penalty, pecuniary or otherwise, shall be inflicted upon the population on account of the acts of individuals for which they cannot be regarded as jointly and severally responsible." Article 33 of the GCIV specifies that "no protected person may be punished for an offence he or she has not personally committed. Collective penalties and likewise all measures of intimidation or of terrorism are prohibited." This prohibition is reinforced by Article 75(2)(d) of the API. The ban on collective punishment does not refer to penalties decided by criminal courts, but rather, it pertains to negative actions of any kind inflicted on persons or entire groups of persons. ${ }^{96}$

The closure of the Gaza Strip affects thousands of people, allegedly due to the actions of some of them against Israeli security. Most of the protected persons that suffer the burden of the Israeli measures are not the addressees of any formal criminal convictions. Rather, they suffer negative consequences of the occupying power's conduct in violation of international humanitarian law only because they are associated with those who threaten Israeli security. Accordingly, the illegality of some specific Israeli practices related to the Gaza Strip closure and their impact on protected persons collectively constitute illegal collective punishment under international humanitarian law, ${ }^{97}$ as emphasized by the UN HRC Special Rapporteur on the situation of human rights in the Palestinian territories in July $2020 .{ }^{98}$

\footnotetext{
${ }^{93}$ See Marco LONGOBARDO, "The Relevance of the Concept of Due Diligence for International Humanitarian Law" (2019) 32 Wisconsin International Law Journal 44 at 54-55.

94 The same argument is applicable to the role of Hamas in relation to the implementation of Israel's negative and positive obligations under international human rights law, as mentioned supra, section II and infra, section V.C.

95 See infra, section $\mathrm{V}$.

96 Jean Pictet, ed., Commentary: IV Geneva Convention Relative to the Protection of Civilian Persons in Time of War (Geneva: International Committee of the Red Cross, 1958), 225.

97 ICRC News Release No. 10/103 (14 June 2010), online: ICRC <www.icrc.org/en/doc/resources/documents/update/palestine-update-140610.htm>; UN Doc. A/HRC/12/48 (2009), 24; Shany, supra note 37 at 102; Shane DARCY, "The Prohibition of Collective Punishment" in Clapham, Gaeta and Sassòli, eds., supra note 28, 1155 at 1162-1163.

${ }^{98}$ UN Doc. A/HRC/44/60 (2020), paras. 53-71.
} 
To comply with international humanitarian law, Israel must find a way to restrict the negative effects of its policies only to those individuals who specifically and directly threaten Israeli security, while, at the same time, respecting the entire array of applicable international law rules. Whilst this article is normative in character and does not dare to offer policy suggestions, it is possible to envisage an increased role of high-tech intelligence and monitoring instruments to tailor the restrictions on freedom of movement.

\section{THE LEGAL UNITY OF THE OCCUPIED PALESTINIAN TERRITORY AS PRE-}

\section{CONDITION OF SAFE PASSAGE}

This Section argues that Israel is bound to consider the Gaza Strip and the West Bank as a single territorial unit. Safe passage between the two areas is a necessary measure to guarantee the unity of the OPT, as recognized by Israel itself in a number of agreements concluded with the PLO. Since Israel, alleging security reasons, prevents the Palestinians from employing seaports and airports to move from the Gaza Strip to the West Bank, and vice versa, Israel must allow the safe passage of the Palestinians through its own territory. However, the Palestinians do not have a right to enter Israel and reside therein, but rather, their entitlement to enter Israel is only linked to safe passage between one portion of Palestinian territory to another.

\section{A. The Gaza Strip and the West Bank as a Single Territorial Unit}

Palestinians have moved between the West Bank and the Gaza Strip relatively freely for years during the occupation. In particular, between 199999 and 2000, ${ }^{100}$ Palestinians were allowed to move between the two areas under the 1999 Protocol Concerning Safe Passage between the West Bank and the Gaza Strip. This situation lasted until Israel decided to suspend safe passage in 2000 as a retaliatory measure in response to the violence that erupted in the OPT (so-called second Intifada), without alleging security reasons. ${ }^{101}$

\footnotetext{
99 See "The Unsafe Road" (8 December 1999), online: Palestinian Centre for Human Rights <www.pchrgaza.org/en/?p=4755>; "Palestinians Queue to Use Safe Route to West Bank", The Guardian (26 October 1999), online: The Guardian <www.theguardian.com/world/1999/oct/26/israel>; UN Doc. E/CN.4/2000/NGO/5 (2000), para. 9.

${ }^{100}$ See "Closures", online: Palestinian Centre for Human Rights < www.pchrgaza.org/Themes/intro.closure.htm>; UN Doc. E/CN.4/2001/112 (2001).

${ }^{101}$ US Department of State, Country Reports on Human Rights Practices for 2001, vol. II (Washington, DC: Department of State, 2002), 2126.
} 
Israel and the PLO undertook to consider the Gaza Strip and the West Bank as a single territorial unit in a number of agreements concluded in the 1990s. Article IV of the 1993 Declaration of Principles reads: "[t]he two sides view the West Bank and the Gaza Strip as a single territorial unit, whose integrity will be preserved during the interim period." Similarly, under Articles XI(1) and $\operatorname{XXXI}(8)$ of the 1995 Interim Agreement, "[t]he two sides view the West Bank and the Gaza Strip as a single territorial unit, the integrity and status of which will be preserved during the interim period." As already mentioned, irrespective of the characterization of Palestine as a state, these agreements are binding treaties under international law because they were concluded between two subjects of international law, a state (Israel) and a national liberation movement (the PLO). Moreover, the Supreme Court of Israel confirmed the idea that the Gaza Strip and the West Bank constitute a single territorial unit in several decisions adopted both before and after the Disengagement, recognizing that " $[\mathrm{t}]$ he two areas are part of mandatory Palestine. They are subject to a belligerent occupation by the State of Israel. From a social and political viewpoint, the two areas are conceived by all concerned as one territorial unit, and the legislation of the military commander in them is identical in content." 102 This case law reinforces the Israeli treaty commitments not to alter the unity of the two areas.

The temporary nature of the occupation obliges the occupying power to respect the status quo ante the occupation, which cannot be lawfully altered by the occupying power's exercise of military force. Accordingly, the characterization of the Gaza Strip and the West Bank as a single territorial unit is in line with the law of occupation, which prevents the occupying power from undertaking permanent changes to the occupied territory. Indeed, the HR emphasizes the temporary nature of the occupying power's administration in a number of provisions, such as Article 43 of the HR, according to which the occupying power must administer the occupied territory "while respecting, unless absolutely prevented, the laws in force in the country", and Article 55, which provides that: "The occupying state shall be regarded only as administrator and usufructuary of [public property]. It must safeguard the capital of these properties, and administer them in accordance with the rules of usufruct". More explicitly, Article 47 of the GCIV stipulates that protected persons in occupied territory "shall not be

\footnotetext{
102 See HCJ 7015/02, 7019/02, Ajuri et al. v. IDF Commander in the West Bank et al. (3 September 2002), para. 22 (unofficial English translation), online: Hamoked <http://www.hamoked.org/files/2010/110_eng.pdf>. See, also, HCJ 11120/05 et al, Hamdan et al. v. Commander of Southern Region et al. (25 July 2007), para. 14 (unofficial English translation), online: ICRC <ihl-databases.icrc.org/applic/ihl/ihlnat.nsf/caseLaw.xsp?documentId=125BF9776A200883C12575BC002B942B\&action=openDocument\&xp_countrySele cted=IL\&xp_topicSelected=GVAL-992BUG\&from=topic\&SessionID=DUJCM3QC81>, according to which "the view of unity of Gaza and the Judea and Samaria area, in the comprehensive Palestinian context, still stands in principle" (references omitted).
} 
deprived, in any case or in any manner whatsoever, of the benefits of the present Convention by ... any annexation by the latter of the whole or part of the occupied territory". Finally, this principle is crystal-clear in Article 4 of the API, according to which "[n]either the occupation of a territory nor the application of the Conventions and this Protocol shall affect the legal status of the territory in question”.

Before the Israeli occupation, the British Mandate comprised the Gaza Strip and the West Bank in the same self-determination unit. ${ }^{103}$ Under the system established by the League of Nations, mandates were used to create and preserve self-determination units, which were protected from dismemberment and permanent alteration. ${ }^{104}$ Since the principle of self-determination of peoples is applicable to the self-determination unit created by the British Mandate, to be lawful, any change of the unity between the Gaza Strip and the West Bank should be the result of a free and genuine expression of the will of the Palestinian people. ${ }^{105}$ This is confirmed by paragraph 6 of the UNGA's Declaration on the Granting of Independence to Colonial Countries and Peoples, according to which "[a]ny attempt aimed at the partial or total disruption of the national unity and the territorial integrity of a country is incompatible with the purposes and principles of the Charter of the United Nations". 106 The application of this rule to self-determination units under occupation is confirmed by the UNGA in a number of resolutions on the self-determination of the Palestinian people, ${ }^{107}$ which demonstrate that any state that limits the self-determination of a people must protect the territorial integrity of that selfdetermination unit. So far, Palestinians have always claimed the unity between the Gaza Strip and the West Bank, as demonstrated by the abovementioned treaty provisions. Accordingly, thanks to the principle of self-determination and as acknowledged by the UNSC, "the Gaza Strip constitutes an integral part of the territory occupied in 1967 and will be a part of the Palestinian State". ${ }^{108}$

\footnotetext{
${ }^{103}$ See James CRAWFORD, The Creation of States in International Law, 2nd ed. (Oxford: Oxford University Press, 2006), 448, note 286.

${ }^{104}$ See Legal Consequences for States of the Continued Presence of South Africa in Namibia (South West Africa) notwithstanding Security Council Resolution 276 (1970), [1971] I.C.J. Rep. 16 at para. 52; David RAIČ, Statehood and the Law of Self-Determination (The Hague, London and New York: Kluwer Law International, 2002), 206-220; Ralph WILDE, International Territorial Administration (Oxford: Oxford University Press, 2008), 167; Kattan, supra note 79 at 128-140. For a critique to the mandate system in relation to the attainment of self-determination, see Anthony ANGHIE, Imperialism, Sovereignty and the Making of International Law (Cambridge: Cambridge University Press, 2007), 115195.

${ }^{105}$ See Chagos opinion, supra nota 81 at para. 160. See, more generally, Victor KATTAN, "Partition", in Rüdiger WOLFRUM, ed., Max Planck Encyclopedia of Public International Law online (Oxford: Oxford University Press, 2011). 106 UN Doc. A/RES/1514 (XV) (1960).

${ }^{107}$ See, e.g., UN Doc. A/RES/74/139 (2019), preamble, which stressed "the need for respect for and preservation of the territorial unity, contiguity and integrity of all of the Occupied Palestinian Territory, including East Jerusalem".

${ }^{108}$ UN Doc. S/RES/1860 (2009).
} 
Consequently, Israel cannot breach the territorial unity of the OPT - irrespective of any view on Palestinian statehood - without violating, at the same time, the law of occupation, the principle of self-determination of peoples, and the accords concluded with the PLO. Consequently, any Israeli policy of separation between the two areas would be illegal under international law.

\section{B. A Right of Passage for the Palestinians}

On a number of occasions, Israel has maintained that, as any sovereign state, it has the right not to admit people demanding entrance into its territory. ${ }^{109}$ Although this view may be correct in principle, ${ }^{110}$ such an argument is untenable in relation to the situation of the Gaza Strip, which is a portion of territory under Israeli occupation.

Israel and the Palestinians consider territorial contiguity between the Gaza Strip and the West Bank to be a key point for the fulfilment of the Palestinian right to self-determination, so that both parties have acknowledged the need to regulate safe passage in any instrument adopted between 1993 and 2005. Article III(7) of Annex II to 1993 Declaration of Principles includes “[a]rrangements for a safe passage for persons and transportation between the Gaza Strip and Jericho area" among the issues to be agreed upon by Israel and the Palestinians. As a result, Articles VII, IX, and XI of Annex I to the 1994 Agreement on Gaza Strip and Jericho Area, Article XXIX and Annex I of the 1995 Interim Agreement, Article 6(4) of the 1998 Wye River Memorandum, ${ }^{111}$ Article 2(b) of the 1999 Protocol, the 2005 Agreed Documents on Movement and Access from and to Gaza ${ }^{112}$ detail the ways in which such a passage should be conducted.

From the standpoint of international law, the situation of transit from the Gaza Strip to and from the West Bank is similar to that addressed by the ICJ in 1960, when Portugal claimed a right of passage to the extent necessary for the exercise of Portuguese sovereignty over some enclaves subject to the regulation and control of India. ${ }^{113}$ Correctly, Portugal pointed out that Portuguese sovereignty

\footnotetext{
${ }^{109}$ See, e.g., AAA4620/11, Qishawi et al. v. Minister of Interior et al. (4 July 2012), para. 5 (unofficial English translation), online: Gisha <gisha.org/UserFiles/File/publications/10_years_10_judgments/Qishawi\%207.pdf>; HCJ 495/12, Azza Izzat et al. v. Minister of Defense (24 September 2012), para. 17 (unofficial English translation), online: Gisha <gisha.org/UserFiles/File/publications/10_years_10_judgments/Izzat\%208.pdf〉; COGAT, supra note 6 at section General.F.

${ }^{110}$ Benedetto CONFORTI, Diritto internazionale, 10th ed. (Napoli: Editoriale Scientifica, 2015), 249.

111 Text in 37 I.L.M. 1251.

$112 \quad$ Text

online:

Israeli

Government

<mfa.gov.il $/ \mathrm{mfa} /$ foreignpolicy/peace/mfadocuments/pages/agreed\%20documents\%20on\%20movement\%20and\%20acc ess\%20from\%20and\%20to\%20gaza\%2015-nov-2005.aspx>.

${ }^{113}$ Case Concerning the Right of Passage over Indian Territory (Merits), [1961] I.C.J. Rep. 6 at 25.
} 
over the area implies the possibility to accede it, and thus, a corresponding duty of India not to bar such a passage. ${ }^{114}$ Although the ICJ did not address this claim specifically, ${ }^{115}$ its judgment held that a series of agreements between Portugal and the various sovereigns over Indian territory are evidence of the existence of local custom in favour of the right of passage. ${ }^{116}$ The ICJ's reasoning echoes the argument of the existence of a right in rem, anciently called international servitude. ${ }^{117}$ Similarly, the Palestinians can claim a right to accede a portion of their territory under the principle of selfdetermination of peoples, and the aforementioned Israeli acknowledgement of a right of passage between 1993 and 2005 is evidence of the customary nature of such a right. The Palestinian claim is even stronger than the Portuguese one since, at that time, the ICJ recognized the Portuguese right to reach some colonial territory - a claim that today would be considered in conflict with the ban on colonial dominions enshrined in customary international law ${ }^{118}$ - whereas the Palestinian claim is based on the principle of self-determination of peoples.

It follows that Palestinians have a right to transit over Israeli territory only to move between the West Bank and the Gaza Strip, rather than to enter Israel and swell therein. It should be emphasized that such a right to passage exists because of the very actions of Israel, which bars entrance and exit to and from the Gaza Strip via airspace and sea routes. As a result, the residents of the area have no alternative way to reach the West Bank other than crossing Israeli territory, and vice versa. Accordingly, the comparison between the Gaza situation with the border between Canada and the US suggested by the Supreme Court of Israel ${ }^{119}$ is groundless since the US is not occupying Canada, nor is it preventing the movement of Canadians through airspace or maritime routes. If Israel wants to avoid the passage of Palestinians through its territory, the Government may decide to let the Palestinians use longer routes not involving passage over the Israeli territory. Indeed, the Israeli decision to exercise some powers connected with the occupation, such as control over the borders of the Gaza Strip and the West Bank, is not a legitimate reason to reduce the rights of protected persons under international humanitarian law, as provided by Article 47 of the GCIV.

\footnotetext{
114 Ibid., Application Instituting Proceedings, 6.

${ }^{115}$ Right of Passage case, supra note 113 at 43.

116 Ibid., at 39-40.

117 Sergio MARCHISIO, “Servitudes” in Wolfrum, ed., supra note 105, (2011), para. 17; Andrew CLAPHAM, Brierly's Law of Nations, 7th ed. (Oxford: Oxford University Press, 2012), 186-187; Alexander ORAKHELASHVILI, Akehurst's Modern Introduction to International Law, 8th ed. (Abingdon: Routledge, 2019), 150-151.

118 See, generally, Cassese, supra note 52 at 71-89.

119 See Azza Izzat case, supra note 109 at para. 17 (par Judge Rubinstein).
} 
Accordingly, the Israeli policy that "approval of the entry of residents of the Judea and Samaria Area to the Gaza Strip is highly limited, for humanitarian cases alone" ${ }^{120}$ is an unlawful measure that aims at breaking the unity of the two areas. The soundness of this conclusion is not altered by the consideration that Egypt controls one small portion of the borders of the Gaza Strip, preventing Palestinians from exiting the Gaza Strip from its southern border (through the Rafah Crossing). ${ }^{121}$ Disappointing as the decision of the Egyptian authorities may be, it cannot be compared to the closure enacted by Israel. Egypt does not prevent the Palestinians from building a seaport or an airport to exit the area, as Israel does, but rather, it only exercises its right to deny entry to foreigners on its own territory. Moreover, even opening the Rafah Crossing would not allow Palestinians from Gaza to reach the West Bank: once in Jordan, they would be stopped by the Israelis who control the border between Jordan and the West Bank.

\section{THE FREEDOM OF MOVEMENT OF PERSONS BETWEEN THE GAZA STRIP AND THE WEST BANK}

\section{A. Limitations to Freedom of Movement under International Humanitarian Law}

This sub-section explores how, in situations of occupation, international humanitarian law allows occupying powers to restrict the freedom of movement of protected persons in some instances. The relevant rules of international humanitarian law should be interpreted in light of applicable international human rights law standards pertaining to freedom of movement. ${ }^{122}$ It is argued that none of these measures can be applied to the entire population of the Gaza Strip, but rather, limitations to the freedom of movement of persons are lawful only if they affect specific individuals.

Article 27(4) of the GCIV affirms that the belligerents may take measures of control and security that are necessary as a result of the war, while Article 78 of the GCIV allows internment and assigned residence as safety measures in relation to protected persons if necessary for imperative reasons of security. Both of these provisions cannot be taken as collective measures, but rather, each case of a protected person must be decided separately. ${ }^{123}$ Article 78 of the GCIV on assigned residence does not apply to the situation of the Gaza Strip since it requires a belligerent "to move certain people from

\footnotetext{
120 COGAT, supra note 6 at Section C.1.

121 The opposite and incorrect claim is advanced, e.g., by Elizabeth SAMSON, "Is Gaza Occupied? Redefining the Status of Gaza under International Law" (2010) 25 American University International Law Review 915 at 944-946.

122 Kolb and Vité, supra note 52 at 344; Darragh MURRAY et al., Practitioners' Guide to Human Rights Law in Armed Conflict (Oxford: Oxford University Press, 2016), 244.

${ }^{123}$ Pictet, supra note 96 at 367.
} 
their domicile and force them to live, as long as the circumstances motivating such action continue to exist, in a locality which is generally out of the way and where supervision is more easily exercised." ${ }^{124}$ Moreover, assigned residence "obviously denotes a measure applicable to one person or one family, not the prohibition to enter or reside in a specified zone imposed upon an anonymous body of people such as all the nationals of a certain state." 125 As confirmed by the ICTY, "the internment and assigned residence, whether in the occupying power's national territory or in the occupied territory, are exceptional measures to be taken only after careful consideration of each individual case. Such measures are never to be taken on a collective basis." 126 Accordingly, the situation of the Gaza Strip as such cannot be characterized as assigned residence, and is not governed by the relevant rules.

The same rationale is applicable to measures under Article 27(4) of the GCIV, of which Article 78 of the GCIV is a specification. Under this provision, "the Parties to the conflict may take such measures of control and security in regard to protected persons as may be necessary as a result of the war." Article 27(4) of the GCIV may be relevant in relation to the closure of the Gaza Strip if the occupying power demonstrates, on a case-by-case basis, that the specific limitation on freedom of movement of one specific individual is necessary as a result of the war. ${ }^{127}$ However, such a limitation is inapplicable to the movement of an unlimited and unidentified number of protected persons such as the entire population of the Gaza Strip. Indeed, as this rule is an exception to the freedom of movement of protected persons in occupied territory, the occupying power must assess the specific individual situation of a protected person in relation to "imperative measures of security" before limiting their freedom of movement.

The fact that the Gaza Strip and the West Bank are a single territorial unit means that Gaza's residents in transit towards the West Bank do not seek to leave the occupied territory. This is an important point because Article 48 of the GCIV only obliges the occupying power to establish procedures to allow neutral protected persons to leave the occupied territory.

\footnotetext{
${ }^{124}$ Ibid., at 256 (emphasis added). The Commentary goes on to affirm that "[i]n that respect [assigned residence] differs from "being placed under surveillance" which was the idea referred to in the International Committee's draft and is a form of supervision which allows the person concerned to remain in his usual place of residence". Consequently, the British view that considers "being placed under surveillance" as a form of assigned residence is inaccurate (UK Ministry of Defence, The Manual of the Law of Armed Conflict (Oxford: Oxford University Press, 2005), section 9.32).

${ }^{125}$ Final Record of the Diplomatic Conference of Geneva of 1949, vol. II(A) (Berne: Federal Political Department, 1978), 826.

${ }^{126}$ Prosecutor v. Delalić, Judgement of 16 November 1998, para. 578 (emphasis added). See, also, Kolb and Vité, supra note 52 at 377.

127 Arai-Takahashi, supra note 57 at 489-490 (referring to measures affecting “individual persons”).
} 
Finally, it is necessary to note that the law of occupation allows the occupying power to reduce the freedom of movement of individuals in exceptional circumstances, such as in the case of pandemics such as the 2020 Covid-19 outbreak. ${ }^{128}$ Indeed, under Article 56 of the GCIV, the occupying power is responsible for "the adoption and application of the prophylactic and preventive measures necessary to combat the spread of contagious diseases and epidemics". ${ }^{129}$ This can be seen as a specification of the duty to restore and ensure public order under Article 43 of the HR. Accordingly, measures aimed at limiting the freedom of moment to avoid the spreading a contagion should be considered lawfully adopted, if they are taken in compliance with human rights law standards on proportionality and necessity.

Absent any situation of hostilities in the Gaza Strip, limitations on the freedom of movement of protected persons may be undertaken only to restore and ensure public order under Article 43 of the HR and to fight against epidemics. This means that the occupying power may limit freedom of movement only following the rules in force in the occupied territory prior to the beginning of the occupation and pursuant to the means available to the ousted sovereign. Accordingly, an occupying power can only limit freedom of movement in light of the applicable rules of domestic law and international human rights law.

\section{B. Freedom of Movement under International Human Rights Law}

International human rights law governs the limitation on the freedom of movement of the population of the occupied territory. Article 12 of the ICCPR is particularly relevant since Israel is a party to this treaty and must apply it when acting in the occupied territory. ${ }^{130}$ Under the first paragraph of this provision, "everyone lawfully within the territory of a state shall, within that territory, have the right to liberty of movement and freedom to choose his residence." According to the Human Rights Committee, this provision "precludes preventing the entry or stay of persons in a defined part of the

\footnotetext{
${ }^{128}$ For the measures adopted by Israel, see OCHA, "COVID-19 Emergency Situation Report 1 (as of 1200 hrs, 24 March 2020)", online: OCHA <www.ochaopt.org/content/covid-19-emergency-situation-report-1>.

${ }^{129}$ For more on this provision, see Marco LONGOBARDO, "The Duties of Occupying Powers in Relation to the Fight against Covid-19”, EJIL:Talk! (8 April 2020), online: EJIL:Talk! <www.ejiltalk.org/the-duties-of-occupying-powers-inrelation-to-the-fight-against-covid-19/>. Compare to Solon SOLOMON, "Israel and its International Law COVID-19 Obligations Towards Gaza", Opinio Juris (04 April 2020), online: Opinio Juris: <opiniojuris.org/2020/04/04/covid-19symposium-israel-and-its-international-law-covid-19-obligations-towards-gaza/> (from the perspective that the Gaza Strip is no longer under occupation).

130 Wall opinion, supra note 24 at para. 111; UN Doc. CCPR/C/ISR/CO/4 (2014), para. 5.
} 
territory." 131 This provision demands that Israel allows the movement of Palestinians between the Gaza Strip and the West Bank, which should be seen as the main components of the same state. The same argument can be advanced if one considers the OPT to be a self-determination unit rather than a state. The conclusion that the rights under Article 12 refer, mutatis mutandis, to movement within a self-determination unit is justified by the need to apply treaty provisions in light of other applicable rules of international law under the VCLT (such as the principle of self-determination of peoples). This interpretation is supported by the fact that the ICJ has considered Article 12 to be applicable to the OPT without holding, at the same, time, that Palestine is a state. ${ }^{132}$

Equally relevant is Article 12(2) of the ICCPR, according to which "everyone shall be free to leave any country, including his own." This provision imposes upon Israel the duty to allow people who live in the Gaza Strip to exit the area to move elsewhere, even if it does not confer any right to dwell within Israeli territory. ${ }^{133}$

The ICCPR provides also for some relevant limitations on the freedom of movement. Article 12(3) of the ICCPR maintains that freedom of movement "shall not be subject to any restrictions except those which are provided by law, are necessary to protect national security, public order (ordre public), public health or morals or the rights and freedoms of others, and are consistent with the other rights recognized in the present Covenant." In situations of occupation, this provision should be interpreted as encompassing also a guarantee for the security of the occupying power and the provision of supplies for the civil populations, in light of the aforementioned international humanitarian law standards. ${ }^{134}$ It also covers situations in which public health requires the limitation of freedom of movement, as in the case of the fight against an epidemic under Article 56 of the GCIV. However, the conditions of legality of any limitations should follow international human rights law also in times of occupation. In particular, as affirmed by the Human Rights Committee, "the restrictions must not impair the essence of the right [and] the relation between right and restriction,

\footnotetext{
131 Human Rights Committee, General Comment No. 27: Article 12 (Freedom of Movement), UN Doc. CCPR/C/21/Rev.1/Add.9 (1999), para. 7. See, also, Art. 13(1) of the Universal Declaration of Human Rights, UN Doc. A/217/A (1948) ("Everyone has the right to freedom of movement and residence within the borders of each state").

${ }^{132}$ Wall opinion, supra note 24 at para. 111. On the duty to interpret treaties in a way that gives them effective meaning, see generally Céline BRAUMANN and August REINISCH, "Effet Utile" in Joseph KLINGLER et al., eds., Between the Lines of the Vienna Convention? Canons and Other Principles of Interpretation in Public International Law (Alphen aan den Rijn: Kluwer Law International, 2019), 47.

${ }^{133}$ See, also, Art. 13(2) of the Universal Declaration of Human Rights ("Everyone has the right to leave any country, including his own, and to return to his country").

${ }^{134}$ Kolb and Vité, supra note 52 at 344.
} 
between norm and exception, must not be reversed." 135 The Human Rights Committee went on to affirm that these restrictions "must conform to the principle of proportionality" and "must be the least intrusive instrument amongst those which might achieve the desired result". ${ }^{136}$ The applicability of these criteria to restrictions of freedom of movement in occupied territory has been authoritatively endorsed by the ICJ in 2004. ${ }^{137}$

It should be noted that states can adopt a number of positive and negative actions to respect, protect, and fulfil their human rights obligations. The basic protection is offered by negative actions, that is, abstention of interference with the enjoyment of a specific right. In relation to the freedom of movement, Israel does interfere with Palestinians enjoyment of their right to free movement. Particularly significant is the Israeli view that Israel maintains full discretion on who can move between Gaza Strip and West Bank. ${ }^{138}$ This position violates Article 12(3), which requires that any limitation on the freedom of movement must be necessary and proportionate in relation to one of the legitimate aims listed by that provision itself. Accordingly, Israel is breaching this rule since it fails to demonstrate case-by-case that the freedom of movement of one specific person from Gaza or into Gaza is a threat to Israeli security. It follows that, even though some threats to Israel originate from the Gaza Strip, the closure of the area and the associated regime of permits is not a lawful response to those threats since they are not the least intrusive instruments among those that might achieve the desired result and they are not proportionate. ${ }^{139}$

Furthermore, Israel facilitates the exit from the Gaza Strip of people who pledge not to return for a long period. ${ }^{140}$ This policy violates Article 12(4) of the ICCPR on the right to enter one's own country, as well as the rights of protected persons to choose where to dwell in the occupied territory without interference from the occupying power, which is protected under Article 49 of the GCIV. ${ }^{141}$ According to the Human Rights Committee, the notion of arbitrariness in Article 12(4) "guarantees that even interference provided for by law should be in accordance with the provisions, aims and objectives of the Covenant and should be, in any event, reasonable in the particular

\footnotetext{
135 UN Doc. CCPR/C/21/Rev.1/Add.9 (1999), para. 13.

136 Ibid., para 14.

${ }^{137}$ Wall opinion, supra note 24 at para. 136.

138 COGAT, supra note 6 at Section B.1.b.

139 UN Doc. CCPR/C/21/Rev.1/Add.9 (1999), para. 14. See also ibid., para. 16; Wall opinion, supra note 24 at para. 136.

140 COGAT, supra note 6 at Section B.5.f.5.

141 Valentina AZAROVA, "From Discretion to Necessity: Third State Responsibility for Israel's Control of Stay and Entry into Palestinian Territory" (2014) 6 Journal of Human Rights Practice 327 at 334.
} 
circumstances." ${ }^{142}$ Article 12(4) is not subject to the restrictions of Article 12(3), so that "the word 'arbitrarily' ('arbitrairement') is to relate exclusively to cases of lawful exile as punishment for a crime, whether this is accompanied by loss of nationality or not." 143

In light of the above considerations, UN human rights monitoring mechanisms have warned Israel on its violations of human rights law in relation to freedom of movement on a number of occasions. In 2014, the Human Rights Committee expressed "concern that the blockade continues to hamper the freedom of movement with only limited categories of persons able to leave Gaza"144 and urged Israel to "[1]ift its blockade of the Gaza Strip, insofar as it adversely affects the civilian population [and to] [e]nsure that any measures restricting the freedom of movement of civilians and the transfer of goods from, into and within Gaza are consistent with its obligations under the Covenant." 145 The Committee went on to affirm that Israel "should take all necessary measures with a view to ensuring respect for the right to freedom of movement for Palestinians throughout the OPT, comprising the West Bank, including East Jerusalem and the Gaza Strip, and ensure that any restrictions on freedom of movement are in line with its obligations under the Covenant." 146 In 2019, the Committee on Economic, Social and Cultural Rights requested Israel "to take immediate steps to facilitate the free movement of Palestinians within the Occupied Palestinian Territory, including East Jerusalem and the Gaza Strip, and ensure that any measures restricting the free movement of civilians and goods from, into and within the Gaza Strip are in line with its obligations under the Covenant". ${ }^{147}$ The same year, the Committee on the Elimination of Racial Discrimination affirmed its concerns "about the longstanding blockade of the Gaza Strip imposed by the State party [which] continues to violate the right to freedom of movement", ${ }^{148}$ urging Israel to "review its blockade policy and urgently allow and facilitate the $[\ldots]$ right to freedom of movement". ${ }^{149}$

Consequently, not only the land closure of the Gaza Strip goes beyond what is permitted to Israel under international humanitarian law, but also breaches the applicable rules of international human rights law.

\footnotetext{
142 UN Doc. CCPR/C/21/Rev.1/Add.9 (1999), para. 21.

143 William A. SCHABAS, Nowak's Commentary on the U.N. International Covenant on Civil and Political Rights, 3rd revised ed. (Kehl: NP Engel, 2019), 326.

${ }^{144}$ UN Doc. CCPR/C/ISR/CO/4 (2014), para. 12.

145 Ibid.

${ }^{146} \mathrm{Ibid}$., at para. 18.

${ }^{147}$ UN Doc. E/C.12/ISR/CO/4 (2019), para. 11(c).

148 UN Doc. CERD/C/ISR/CO/17-19 (2019), para. 44.

149 Ibid., at para. 45.
} 


\section{Freedom of Movement under the 1999 Protocol Concerning Safe Passage between the West}

Bank and the Gaza Strip and the 2005 Agreed Documents on Movement and Access from and to

\section{Gaza}

The commitments undertaken by Israel with the 1999 Protocol Concerning Safe Passage between the West Bank and the Gaza Strip and the 2005 Agreed Documents on Movement and Access from and to Gaza, which directly address the freedom of movement of persons, complement the applicable legal framework to freedom of movement of persons between the two areas. To the best knowledge of this author, these agreements have never been formally terminated by Israel or by the Palestinians. Admittedly, if they are considered as treaties between a state and a movement of national liberation, as this author does, one could wonder which are the rules applicable to these instruments: in fact, the VCLT is not formally applicable ${ }^{150}$ and one should investigate customary international law rules developed on the basis of the scant state practice and opinio juris pertaining to treaties concluded between a state and a movement of national liberation. However, since all the rules on treaty termination require a written notification, ${ }^{151}$ it is possible to argue that even the termination of the 1999 Protocol and the 2005 Agreed Documents would have required such a procedure, which, to the best knowledge of this author, has not been followed. ${ }^{152}$ Indeed, the ongoing applicability of these agreements is confirmed by the practice of the UNSC and the UNGA, which have invoked their implementation on a number of recent occasions. ${ }^{153}$

According to Articles 2(b)(1) and 2(c) of 1999 Protocol, Israel must ensure safe passage for persons and transportation during daylight hours, not less than 10 hours a day, both by means of privately owned road vehicles and public transportation. Under Article 2(c)(2), Israel must allow persons to travel through the Erez crossing point, the Tarkumya crossing point, and an additional crossing point around Mevo Horon.

\footnotetext{
150 See arts. 1 and 3.

${ }^{151}$ See art. 67(1) of the VCLT, according to which the 'notice' of termination under art. 65(1) must be in writing.

${ }_{152}$ Mutatis mutandis, see what happened with the Agreement on a Temporary International Presence in Hebron (21 January 1997), online: Israeli Government $<$ mfa.gov.il/mfa/foreignpolicy/peace/guide/pages/agreement\%20on\%20temporary\%20international\%20presence\%20in $\% 20$ h.aspx >), according to which an international observer mission was deployed in Hebron. In 2019, Israel decided to terminate the agreement, withdrawing its consent to the presence of the mission ("Israel to boot international observers out of Hebron, Netanyahu says", The Times of Israel (28 January 2019), online: The Times of Israel <www.timesofisrael.com/israel-to-boot-international-observers-out-of-hebron-netanyahu-says/>).

153 See, e.g., UN Doc. S/RES/1860 (2009), para. 6; UN Doc. A/RES/74/89 (2019), para. 14.
} 
Article 2(g) of the 1999 Protocol - according to which Israel may modify the route or enact closures for security or safety reasons only temporarily, ensuring that one of the routes is kept open for safe passage - clearly outlaws indefinite closures such as the one currently in place. Israel violates the Protocol also when it bars passage indiscriminately to different groups of persons, whereas Article 2(h) of the Protocol only permits denial of passage to persons who have seriously or repeatedly violated the safe passage provisions detailed in the agreement.

Residents of the Gaza Strip have the right to enter Israel to reach the West Bank, as provided by Article 2(f) of the 1999 Protocol and as a consequence of the duty to consider West Bank and Gaza Strip as a single territorial unity. As Israel has bound itself to allow passage on its own territory rather than through other routes, now it is under a duty to allow passage of persons from Gaza and the West Bank, without renouncing its sacrosanct right to impose security inspections on the persons that transit through its territory. ${ }^{154}$

Under the terms of the 1999 Protocol, the Palestinian Authority Civil Affairs Office should work with Israel on the passage to and from the West Bank and Gaza, receiving applications from Palestinians and submitting them to Israel after a preliminary screening. ${ }^{155}$ Since the 1999 Protocol implements a duty established under the law of occupation according to Articles 7 and 47 of the GCIV, any lack of cooperation by the Palestinian leadership in the Gaza Strip does not relieve Israel from its obligations to allow safe passage as far as possible in compliance with the agreed terms. ${ }^{156}$

\section{Issues Concerning Selected Specific Persons}

This sub-section briefly addresses the restrictions on the freedom of movement from and to the Gaza Strip of two special groups of individuals: medical patients and students. The analysis of the relevant legal regime demonstrates lack of compliance with relevant international law standards.

\section{Permits for persons requiring medical treatment}

Israel has conceded some permits for exiting the Gaza Strip due to health reasons. In particular, sometimes Israel allows people to leave the Gaza Strip in order to receive life-saving or life-changing medical treatment, to accompany underage children who needs the same medical treatments, to

\footnotetext{
154 Art. 2(i) of the 1999 Protocol.

155 UN Doc. A/73/420 (2018), paras. 16-17.

156 See, mutatis mutandis, art. 60(5) of the VCLT. One author noted that the safe passage provisions of these agreements "really require more concessions by Israel than the Palestinians" (Watson, supra note 69 at 143).
} 
accompany a patient, and to visit patients (i.e., a first-degree relative who requires protracted hospitalization, including in rehabilitation facility or in home hospitalization requiring medical supervision and monitoring, or a patient who is seriously ill with a potentially life-threatening condition). ${ }^{157}$ According to the World Health Organization (WHO), "in 2018, patients applying to exit Gaza for healthcare had the second lowest approval rate recorded by WHO since 2006, with $15,834(61.4 \%)$ of 25,811 patient permit applications approved." 158 The WHO went on to state that, although " $[\mathrm{t}]$ he reason for unsuccessful application is not stated in $70 \%$ of denials", however, "[d]elays of patient permit applications continue to represent the largest reason for non-approval, with 8,017 or $31.0 \%$ of patients receiving no definitive response ... before the time of their hospital appointment." 159

Under the law of occupation, Israel has the duty to take care of the healthcare of the Gazan residents in the framework of the obligation to restore and ensure civil life under Article 43 of the HR and under Article 56 of the GCIV. Although the degree of control exercised by Israel is limited by the Hamas administration so that Israel is not required to take positive measures in the area, nonetheless, Israel maintains the responsibility not to raise any obstacle to the exercise of the right to health of the population in the Gaza Strip, in the form of a negative obligation of non-interference. ${ }^{160}$ Accordingly, the Israeli permit policy, based on arbitrary decisions of the Israeli authorities, violates the law of occupation, since it creates an unjustified barrier to the enjoyment of healthcare for the local population.

Moreover, the Israeli practice is unlawful under Article 12 of the ICESCR, according to which states must allow the treatment of diseases and create conditions that would assure access to all medical services and medical attention in the event of sickness. Under this rule, the right to health does not comprise only life-saving and life-changing treatments, but focuses on "the highest attainable standard of health." This includes also physical accessibility to "health facilities, goods and services," 161 which is not granted to the residents of the Gaza Strip. Consequently, the UN Committee on Economic, Social and Cultural Rights expressed concerns that Palestinians living in the Gaza Strip

\footnotetext{
157 See COGAT, supra note 6 at Sections B.2 and B.5.f.1 (for treatment abroad).

158 WHO, Right to Health in the Occupied Palestinian Territory: 2018 (Cairo: WHO, 2018) 39.

159 Ibid.

${ }^{160}$ Gilles GIACCA and Ellen NOHLE, "Positive Obligations of the Occupying Power: Economic, Social and Cultural Rights in the Occupied Palestinian Territories” (2019) 19 Human Rights Law Review 491 at 512.

${ }_{161}$ Committee on Economic, Social and Cultural Rights, General Comment No. 14: The Right to the Highest Attainable Standard of Health (Art. 12), UN Doc. E/C.12/2000/4 (2000), para. 12(b).
} 
have severely restricted access to health facilities, goods and services, ${ }^{162}$ and requested Israel to "(a) Facilitate the entry of essential medical equipment and supplies and the movement of medical professionals from and to Gaza; (b) Review the medical exit-permit system with a view to making it easier for residents of Gaza to access, in a timely manner, all medically recommended health-care services; (c) Ensure that all children referred for medical treatment outside Gaza can be accompanied by at least one parent." ${ }^{163}$ Similarly, in the framework of the Universal Periodic Review, a number of states have urged Israel to lift its restrictions on the freedom of movement in the Occupied Palestinian Territory in order to allow the enjoyment of the human right to health. ${ }^{164}$

Additionally, credible reports have highlighted the arbitrariness of some Israeli decisions. For instance, cancer patients were denied entry or did not receive any reply to their request for permission to cross the Gaza Strip border, ${ }^{165}$ or had their permission conditioned on the provision of information pertaining to armed groups in the Gaza Strip. ${ }^{166}$ Taking into account the impact on mental and physical health of such vulnerable patients, this practice amounts to inhumane treatment, ${ }^{167}$ which is prohibited by peremptory rules of international humanitarian law and international human rights law. Moreover, the use of permits for health reasons to induce the population of occupied territory to collaborate with the occupying power is a violation of Article 44 of the HR, according to which "a belligerent is forbidden to force the inhabitants of territory occupied by it to furnish information about the army of the other belligerent, or about its means of defence."

\section{Permits for students}

Whereas Israel acknowledges that Palestinians from the West Bank may desire to enter Israel for educational purposes, ${ }^{168}$ Israel does not list education as one of the grounds for applying for a permit from the Gaza Strip into the West Bank. The only ground for education that is generally recognized

\footnotetext{
162 UN Doc. E/C.12/ISR/CO/3 (2011), para. 32; UN Doc. E/C.12/ISR/CO/4 (2014), para. 58.

163 Ibid., at para. 59.

164 See, e.g., the positions of Australia (UN Doc. A/HRC/25/15 (2013), para. 136.67; UN Doc. A/HRC/38/15 (2018), para. 118.101); Maldives (UN Doc. A/HRC/25/15 (2013), para. 118.174); Canada (ibid., at para. 118.176).

165 WHO, supra note 158 at 35.

166 UN Doc. A/73/420 (2018), para. 18.

167 "Inhuman treatment" in international human rights law refers to a treatment that causes either actual bodily injury or intense mental or physical suffering (Human Rights Committee, General Comment No. 20 (Art. 7) (Prohibition of Torture, or Other Cruel, Inhuman or Degrading Treatment or Punishment), UN Doc. A/44/40 (1992), para. 5; ECtHR, Labita v. Italy, Judgement of 8 April 2000, para. 120; ECthR, Kudka v. Poland, Judgment of 26 October 2000, para. 92). Under international humanitarian law, "inhuman treatment" is defined as "an intentional act or omission ... which is deliberate and not accidental, which causes serious mental or physical suffering or injury or constitutes a serious attack on human dignity" (Delalić case, supra note 126 at para. 543.)

168 COGAT, supra note 6 at Section A.3.
} 
pertains to study abroad: Israel permits "travel by students for academic studies abroad (all degrees) and certification studies (engineers and technicians)" as well as "entry for the purpose of travel abroad ... by residents of the Gaza Strip who are the recipients of a scholarship granted by a country that maintains diplomatic relations with the State of Israel, or an IO recognized by the State of Israel". 169 Additionally, a specific ground for requesting permits pertains to those residents of Gaza who want "to receive medical training." 170

The Israeli policy is a blanket ban on Gazan students who want to develop an education in the West Bank or in Israel, in contrast to the past practice of many youths from the Gaza Strip who attended West Bank universities. ${ }^{171}$ This is a discriminatory measure since students from the West Bank are allowed to enter into Israel for educational purposes. Nonetheless, in relation to the requests to study abroad, the Supreme Court of Israel has recognized the freedom of the government to grant permits on the basis of discretional political interests. ${ }^{172}$

The law of occupation prescribes that an occupying power must facilitate the education of children only, under Article 50 of the GCIV. Nevertheless, education of children and adults falls under the scope of the duty to restore and ensure civil life under Article 43 of the HR. ${ }^{173}$ Accordingly, as far as possible, Israel must act diligently and in good faith to grant education of the Gaza residents. Since Israel prevents the access to educational institutions, it is not complying with the minimum standard of conduct (non-interference) required by Article 43 of the HR.

International human rights law is a source of more detailed obligations incumbent upon Israel. Article 13 of the ICESCR recognizes that the right to education applies to everybody and that "higher education shall be made equally accessible to all, on the basis of capacity, by every appropriate means, and in particular by the progressive introduction of free education." Since the right of education entails physical accessibility of educational facilities, ${ }^{174}$ Israel, as the occupying power responsible for the Gaza Strip, has the duty to facilitate the access to education centres for Gazan residents, on a non-discriminatory basis, prioritizing the access to those programmes that are currently unavailable in the Gaza Strip. Accordingly, the UN Committee on Economic, Social and Cultural Rights

\footnotetext{
${ }^{169}$ Ibid., at Sections B.5.f.3 and B.5.f.4.

170 Ibid., at Section B.2.d.

171 UN Doc. A/73/420 (2018), para. 26.

172 See, e.g., Azza Izzat case, supra note 109 at para. 4 (Justice Naor).

173 Jam'iat Iscan Al-Ma'almoun case, supra note 90 at para. 18.

174 Committee on Economic, Social and Cultural Rights, General Comment No. 13: The Right to Education (Art. 13), UN Doc. E/C.12/1999/10 (1999), para. 6(b).
} 
expressed concerns "about the blanket ban on education in the West Bank imposed since 2014 on students from the Gaza Strip, which has limited their access to higher education in particular." 175 The Committee went on to lament "the serious impact of the dual-use list on the ability of students in the Gaza Strip to enjoy their right to education, particularly in the fields of science and engineering, and the benefits of scientific progress and its applications due to the lack of essential education materials and equipment (arts. 13 and 15)". ${ }^{176}$ The Committee concluded by urging Israel "to lift the abovementioned blanket ban and to allow the entry into Gaza of the materials and equipment necessary for educating students in the fields of science and engineering." 177

On these bases, Israeli refusal to grant any permit to potential students from Gaza who aspire to study in the West Bank is a violation of international law, both under the law of occupation and the ICESCR. To comply with its obligations, Israel should allow the movements of students between the two areas of the Occupied Palestinian Territory.

\section{MOVEMENT OF GOODS BETWEEN THE GAZA STRIP AND THE WEST BANK}

\section{A. Goods that Are Essential for the Population of the Occupied Territory}

The law of occupation governs the transit of goods in relation to the welfare of the inhabitants of the occupied territory, with the aim of guaranteeing an adequate standard of living. These rules are applicable to the transit of goods from the Gaza Strip to the West Bank, even though different kinds of goods are treated differently under international law. The legal framework is complemented by Article 8 of the 1999 Protocol, which identifies the Karni crossing point for passage of commercial goods, without providing any detailed list of goods that can be allowed in the Gaza Strip.

Before analysing the relevant provision, it is necessary to mention briefly the dire living conditions of the Gaza Strip. According to the World Food Programme, "the humanitarian conditions in Gaza where poverty and food insecurity affect 53 percent and 68.5 of the population respectively - continue to deteriorate at an alarming pace following the collapse of all productive sectors, basic social services and infrastructures." 178 The World Food Programme stressed that "Gaza's socio-economic fabric is faltering due to the cumulative impact of 11 years of sea, land and air blockade."179

\footnotetext{
175 UN Doc. E/C.12/ISR/CO/4 (2019), para. 66.

176 Ibid.

177 Ibid., at para. 67.

178 World Food Programme, "Palestine”, online: 〈www.wfp.org/countries/palestine>.
} 
The first international law provision that should be taken into account is the duty to restore and ensure civil life in occupied territory, under Article 43 of the HR. This rule obliges the occupying power to abstain from creating barriers to the development of the economy within the occupied territory. Some goods, such as those related to food, healthcare, and education, are strictly instrumental to the enjoyment of civil life.

Moreover, the occupying power cannot use starvation as a method of warfare. According to Article 54(1) of the API, "starvation of civilians as a method of warfare is prohibited." Paragraph 2 of the same provision affirms that "it is prohibited to attack, destroy, remove or render useless objects indispensable to the survival of the civilian population ... for the specific purpose of denying them for their sustenance value to the civilian population or to the adverse Party, whatever the motive, whether in order to starve out civilians, to cause them to move away, or for any other motive." Under international law, "starvation" means "causing the population to suffer hunger, particularly by depriving it of its sources of food or of supplies." 180 The treaty rules on starvation correspond to customary international law ${ }^{181}$ and their violation is a war crime under Article 8(2)(b)(25) of the 1998 Rome Statute of the International Criminal Court (ICC). Less stringent rules apply to a blockade, which is unlawful if it "has the sole purpose of starving the civilian population or denying it other objects essential for its survival". ${ }^{182}$ On the other hand, the modern ban on starvation is almost entirely incompatible with traditional siege warfare, which must be adapted today to allow the exit of the civilian population from the besieged area. ${ }^{183}$ Accordingly, the occupying power must allow the entrance in the occupied territory of goods that are necessary to avoid starvation.

Israel violated the prohibition of starvation until 2015, when the government calculated the amount of calories required by the residents of Gaza for survival, blocking any exceeding goods. ${ }^{184}$ Even

\footnotetext{
179 ibid.

180 Yves SANDOZ, Charles SWINARSKI and Bruno ZIMMERMANN, eds., Commentary on the Additional Protocols of 8 June 1977 to the Geneva Conventions of 12 August 1949 (Leiden: Martinus Nijhoff, 1987), para. 2089.

181 Henckaerts and Doswald-Beck, eds., supra note 48 at 189.

182 Art. 102(a) of the San Remo Manual on International Law Applicable to Armed Conflicts at Sea (Cambridge: Cambridge University Press, 1994) (emphasis added). Other grounds of illegality of a blockade cannot be explored here.

183 Henckaerts and Doswald-Beck, eds., supra note 48 at 188; Sean WATTS, "Under Siege: International Humanitarian Law and Security Council Practice Concerning Urban Warfare" (May 2014) Harvard Law School Project on Law and Security 1 at 10-11.

184 See Ayel GROSS and Tamar FELDMAN, “We Didn’t Want to Hear the Word 'Calories': Rethinking Food Security, Food Power, and Food Sovereignty_Lessons from the Gaza Closure” (2015) 33 Berkeley Journal of International Law 379; Orna BEN-NAFTALI, Michael SFARD, Hedi VITERBO, The ABC of the OPT: A Legal Lexicon of the Israeli Control over the Occupied Palestinian Territory (Cambridge: Cambridge University Press, 2018), 343-361.
} 
though this policy was envisaged not to lead anybody to death for lack of food, ${ }^{185}$ it caused the population to suffer serious hunger, which is one of the situations falling under the definition of starvation. Happily, this policy has been repealed amid widespread outrage after it was made public.

Moreover, Article 55 of the GCIV demands that "to the fullest extent of the means available to it, the Occupying Power has the duty of ensuring the food and medical supplies of the population; it should, in particular, bring in the necessary foodstuffs, medical stores and other articles if the resources of the occupied territory are inadequate." This duty applies with regard to the entire population of the occupied territory rather than to civilians only, so that an occupying power is not relieved from this duty only because combatants infiltrated the civilian population. ${ }^{186}$ Article 69 of the API widens the scope of this duty, requiring that the occupying power must supply "clothing, bedding, means of shelter, other supplies essential to the survival of the civilian population of the occupied territory and objects necessary for religious worship." Accordingly, allowing the entrance of all these goods into the Gaza Strip would be a way to comply with these duties, whereas denial is a violation of these obligations. ${ }^{187}$ This is particularly relevant with reference to medical instruments, which are urgently needed in the Gaza Strip. ${ }^{188}$

Additionally, the occupying power has specific duties in relation to the transit of goods that are instrumental for the fight against pandemics such as the 2020 Covid-19 outbreak. As mentioned above, under Article 56 of the GCIV, the occupying power is responsible for "the adoption and application of the prophylactic and preventive measures necessary to combat the spread of contagious diseases and epidemics." This last reference means that, to fight a contagious disease, an epidemic, or a pandemic, the occupying power must allow the transit in the occupied territory of specific medical supplies that may be needed to monitor and fight the contagion. Although the Government of Israel reported that it is allowing the transit of medical supplies into the Gaza Strip to fight against the virus, ${ }^{189}$ the healthcare institutions of the Gaza Strip appear to be significantly underequipped to fight against Covid-19. 190

\footnotetext{
185 See Al-Bassiouni case, supra note 22 at para. 15, where the position of the government of Israel on the ban on starvation is succinctly summarized. As usual, without any independent inquiry, the Supreme Court of Israel deferred to the government in relation to the assessment of the security situations and in relation to the assurances that the basic needs of the local population were met (ibid., para. 20).

186 Pictet, ed., supra note 96 at 310.

187 Flavia LATTANZI, "Humanitarian Assistance" in Clapham, Gaeta and Sassòli, eds., supra note 28, 231 at 247.

188 Bowirrat ABDALLA et al., "The Growing Burden of Cancer in the Gaza Strip" (2019) 8 The Lancet Oncology 1054.

189 Israel, "Briefing for foreign ambassadors on Coronavirus management and cooperation with the Palestinians" (31 March 2020), online: Israeli Government: <mfa.gov.il/MFA/PressRoom/2020/Pages/Briefing-for-foreign-ambassadorson-Coronavirus-management-and-cooperation-with-the-Palestinians-31-March-2020.aspx>.
} 
Finally, the limitation on transportation of some specific goods affects some rights protected by the ICESCR. In particular, all limitations on foodstuff, clothing, and housing items must comply with the right to adequate standards of living under Article 11. All limitations on the transit of medical supplies must be in line with the right to health pursuant to Article 12. All limitations on educational goods must respect the right to education embodied in Article 13. Under the ICESCR, states must not interfere with the enjoyment of these rights and any limitation must be necessary and proportionate.

Accordingly, the current policy of Israel in relation to essential goods in the Gaza Strip violates international humanitarian law and international human rights law. Not only should Israel allow the transit of essential goods, but also, it should bring in the relevant items if the local population is not adequately supplied.

\section{B. Relief Goods in the Gaza Strip}

The law of occupation embodies provisions to address a situation in which, notwithstanding the efforts of the occupying power, the population of the occupied territory is not adequately supplied. Under these circumstances, the occupying power must consent to the consignment of relief from states or humanitarian organizations.

Under Article 59(1) of the GCIV, "if the whole or part of the population of an occupied territory is inadequately supplied, the occupying power shall agree to relief schemes on behalf of the said population, and shall facilitate them by all the means at its disposal." This provision embodies two separate obligations, pertaining to consent to relief operations and facilitation of the relief operation. ${ }^{191}$

The GCIV does not provide the occupying power any ground for rejecting relief. ${ }^{192}$ In nonoccupied territory, a state can withhold consent to relief operations, since Article 70(1) of the API considers the consent of the state as a condition for the undertaking of the relief operation. The view that the same consideration should apply also in occupied territory ${ }^{193}$ is untenable since Article $70(1)$ of the API explicitly does not apply to occupied territory, as provided both by this provision and by

\footnotetext{
190 OCHA, supra note 128.

191 Lattanzi, supra note 187 at 247.

192 Pictet, ed., supra note 96 at 320; Lattanzi supra note 187 at 242; Dapo AKANDE and Emanuela-Chiara GILLARD, "Oxford Guidance on the Law Relating to Humanitarian Relief Operations in Situations of Armed Conflict" (2016), para. 32, online: UN OCHA, <www.unocha.org/sites/dms/Documents/Oxford\%20Guidance\%20pdf.pdf>; Dinstein, supra note 12 at 206-207.

193 Arai-Takahashi, supra note 57 at 360.
} 
Article 69(2) of the API. Moreover, it is reasonable to afford more relevance to the consent of a state in relation to relief to its own population (Article 70(1) of the API) rather than in relation to occupied territory (Article 56 of the GCIV), where the occupying power's administration has narrower powers to limit the rights of the local population. Accordingly, the occupying power cannot refuse access within its territory to foodstuff, medical supplies, and clothing (listed in Article 59(2) of the GCIV) if relief operations are offered by other states and/or international organizations and/or NGOs who act in impartial and purely humanitarian ways. The occupying power can negotiate technical arrangements such as those pertaining to performance of inspections and security checks over the relief consignments. ${ }^{194}$ These arrangements must be in accordance with applicable international human rights and humanitarian law, must be negotiated in good faith, and must be necessary and proportionate to fulfil the needs of the inhabitants of the occupied territory. ${ }^{195}$ The occupying power can reject relief from one supplier on the basis of its origins only if the local population of the occupied territory is adequately supplied in other ways. ${ }^{196}$

Applying these rules to the closure of the Gaza Strip, it is apparent that, in light of the humanitarian crisis in the area, Israel must allow the consignment of foodstuff, medical supplies, and clothing offered by impartial states, international organization, and NGOs, as asked by the UN on a number of occasion. For instance, in 2009, the UNSC called for "the unimpeded provision and distribution throughout Gaza of humanitarian assistance, including of food, fuel and medical treatment". ${ }^{197}$ The Israeli refusal may be punished as a war crime under Article 8(2)(b)(xxv) of the ICC Statute, which includes "wilfully impeding relief supplies as provided for under the Geneva Conventions" in the definition of the war crime of starvation.

\section{REMEDIES AGAINST THE ISRAELI VIOLATIONS OF INTERNATIONAL LAW}

\section{A. The Role of Palestine}

There is no doubt that every internationally wrongful act of a state entails its international responsibility, as stated by Article 1 of the DARS. This principle applies to the breaches of all of the

\footnotetext{
194 Akande and Gillard, supra note 192 at paras. 33 and 67.

195 Ibid., at para. 71.

196 Ibid., para. 33.

197 UN Doc. S/RES/1860 (2009), para. 2.
} 
rules mentioned in the previous sections as long as those violations are attributable to Israel ${ }^{198}$ and absent any circumstance precluding wrongfulness. ${ }^{199}$

The international responsibility of Israel means that this state is under a continued duty to perform the obligations breached, under Article 29 of the DARS. Pursuant to Article 30, Israel must cease all the violations and offer appropriate assurances and guarantees of non-repetition. Applying Articles 31, 34-37 of the DARS, Israel must make full reparation for the injury caused by the internationally wrongful act, in the form of restitution (if possible) or compensation. In the circumstances of the Gaza Strip closure, this means that Israel must re-establish safe passage of persons between the Gaza Strip and the West Bank, at the conditions agreed in the 1999 Protocol and in compliance with the relevant rules of the law of occupation and international human rights law. Israel must also allow the transit of goods into and from the Gaza Strip in line with the law of occupation, international human rights law, and the 1999 Protocol. Moreover, Israel is under a duty to pay compensations for the damage caused to Palestinians so far.

The primary entitlement to react to the Israeli violations stays with the Palestinians, whether Palestine is a state or not. Palestine has invoked the responsibility of Israel on a number of occasions, to no avail so far. Under Articles 49-53 of the DARS, Palestine is also entitled to undertake countermeasures with the goal of inducing Israeli compliance. These countermeasures must respect the ban on the use of armed force, international human rights and international humanitarian law rules, other jus cogens rules, diplomatic immunities, and the rules established to the peaceful settlement of international disputes. However, in light of the ongoing occupation of the entire territory of Palestine, it is highly unlikely that Palestine will be able to react by adopting countermeasures in an effective way.

Article 1(7) of the UN Charter demands that any dispute is solved peacefully, through diplomatic or adjudicative means that are exemplified in Article 33. Although Palestine is a member of the ICJ

\footnotetext{
198 See art. 2 of the DARS.

199 These are listed by arts. 20-26 of the DARS. It is impossible to address their role in relation to the Gaza Closure. Suffice it to say that some of them are inapplicable or apply differently to international humanitarian law: e.g., the state of necessity cannot be applied to violations of jus in bello because the impact of necessity in this field has already been taken into account in the codification of the relevant primary rules (under the label of "military necessity"). See Commentary to art. 25 of the DARS, para. 21. See, generally and for further references, Marco LONGOBARDO, "Rapporti fra strumenti di codificazione: il progetto di articoli sulla responsabilità degli Stati e le convenzioni di diritto internazionale umanitario" (2018) 101 Rivista di diritto internazionale 1136 at 1155-1161.
} 
Statute, ${ }^{200}$ in the absence of a specific consent by Israel, Palestine cannot bring the claim of Israeli responsibility before the ICJ. ${ }^{201}$ However, the lack of a forum that can address a violation of international law is irrelevant in relation to the duty to comply with the breached rules.

\section{B. The Role of Other States and International Organizations}

States other than Palestine and international organizations can play a role in relation to the Israeli violations of international law pertaining to the closure of the Gaza Strip. Although they overlap partially, two different levels must be kept separate: actions that other states must undertake under some primary rules versus actions that other states and international organization may undertake under the law of international responsibility.

In relation to the first level, all the states parties to the GCs - that is, all the states in the world are under a duty to respect and ensure respect for international humanitarian law under Article 1 Common to the Four GCs. As suggested by doctrine, ${ }^{202}$ recognized by the ICRC, ${ }^{203}$ and acknowledged by the ICJ, ${ }^{204}$ the duty to ensure respect for international humanitarian law implies the duty to react to other states' violations of international humanitarian law. States have a duty to endeavour diligently so that other states do not violate international humanitarian law. ${ }^{205}$ Possible actions include: addressing questions of compliance through diplomatic channels, exerting diplomatic pressure; conditioning joint operations on a coalition partner's compliance with its obligations; referring, where applicable, a situation to competent international bodies; applying measures of retorsion; and adopting lawful countermeasures. ${ }^{206}$ Accordingly, under Common Article 1, all the states in the world must endeavour to persuade Israel to comply with the international humanitarian law rules that are violated by the closure of the Gaza Strip. The limit to permissible actions based on Common Article 1 is that other states cannot violate international law, and in particular Israeli rights,

\footnotetext{
${ }^{200}$ ICJ, "States Not Parties to the Statute to Which the Court May Be Open", online: ICJ: <www.icjcij.org/en/states-not-parties>.

201 East Timor (Portugal v. Australia), [1995] I.C.J. Rep. 90 at para. 26.

202 See, e.g., Luigi CONDORELLI and Laurence BOISSON DE CHAZOURNES, "Quelques remarques à propos de l'obligation des États de 'respecter et faire respecter' le droit international humanitaire 'en toutes circonstances"' in Christophe SWINARSKI, ed., Etudes et essais sur le droit international humanitaire et les principes de la Croix-Rouge en l'honneur de Jean Pictet (Leiden: Martinus Nijhoff, 1984), 17; Robin GEISS, "The Obligation to Respect and to Ensure Respect for the Conventions" in Clapham, Gaeta and Sassòli, eds., supra note 28, 111 at 123.

203 Jean-Marie HENCKAERTS, "Article 1: Respect for the Convention" in International Committee of the Red Cross, Updated Commentary on the First Geneva Convention (Cambridge: Cambridge University Press, 2016), paras. 153-191. 204 Wall opinion, supra note 24, para. 158.

205 Geiss, supra note 202 at 127-130; Henckaerts, supra note 203 at para. 150.

206 Some of these are listed ibid., at para. 181.
} 
in order to fulfil their duty to ensure respect, ${ }^{207}$ apart from those violations that are justified by international law itself (e.g., pursuant to a circumstance precluding wrongfulness).

On the second level, other states and international organizations may invoke the consequences of the violations of some particular kinds of obligations. For instance, this is the legal basis of the several criticisms against Israel for lack of respect for the freedom of movement of the Palestinians in the framework of the Universal Periodic Review. ${ }^{208}$ Moreover, under Articles 40 and 41 of the DARS, in cases of gross or systematic failures to fulfil a peremptory norm of general international law (jus cogens), states shall cooperate to bring to an end through lawful means the breach, and must not recognize as lawful a situation created by such a breach, nor render aid or assistance in maintaining that situation. Article 42 of the 2011 ILC's Draft Articles on the Responsibility of International Organizations (DARIO) mentions similar obligations in relation to cooperation between states and international organizations. It is undisputed that the principle of self-determination of peoples is jus cogens, ${ }^{209}$ as well as some rules of international humanitarian law. ${ }^{210}$ This duty of cooperation is mirrored by Article 89 of the API, according to which "in situations of serious violations of the Conventions or of this Protocol, the High Contracting Parties undertake to act, jointly or individually, in co-operation with the [UN] and in conformity with the [UN] Charter."

Moreover, Article 48 of the DARS governs the entitlement to react against an international wrongful act by states other than the directly injured one. If an obligation is owed towards the international community as a whole (erga omnes) or all the states parties to a specific convention (erga omnes partes), every state in the international community or party to that convention can 1) invoke responsibility; 2) demand cessation and assurances and guarantees of non-repetition; and 3) demand the performance of the obligation of reparation in the interest of the injured state or of the beneficiaries of the obligation breached. In both cases, states other than the directly injured one can adopt countermeasures. ${ }^{211}$ Similar rules are embodied in Article 49 of the DARIO in relation to the

\footnotetext{
207 Ibid., at para. 174.

${ }^{208}$ See, in addition to the remarks referred to supra note 164, the views expressed in UN Doc. A/HRC/25/15 (2013) by Thailand (para. 47), Ecuador (para. 136.107), Malaysia (paras. 136.109 and 136.217), France (para. 136.144), Switzerland (para. 136.214), Chile (para. 136.215), Spain (para. 136.220), and Saudi Arabia (para. 137.3), and in UN Doc. A/HRC/38/15 (2018) by Germany (para. 118.73), Ecuador (para. 118.152), Iceland (para. 118.172), Turkey (para. 118.173), Maldives (para. 118.174), Malaysia (para. 118.175), Canada (para. 118.176), and Switzerland (para. 118.186). ${ }^{209}$ ILC, Fourth report of the Special Rapporteur, Dire TLADI, UN Doc. A/CN.4/727 (2019), paras. 108-115.

210 See Nuclear Weapons opinion, supra note 56 at para. 79; Jurisdictional Immunities case, supra note 85 at para. 93; ILC, supra note 209 at paras. 116-121; David, supra note 31 at 105-114.

211 Although the question is left open by art. 54 of the DARS, there is consensus that customary international law evolved so that other states may adopt countermeasures (Institut de Droit International, Krakow session, Resolution of 27 August
} 
entitlements of international organizations. The ICJ has recognized that both the principle of selfdetermination of peoples ${ }^{212}$ and international humanitarian law obligations are obligations erga omnes. ${ }^{213}$ Moreover, the rules enshrined in the ICCPR, including the principle of self-determination of peoples under Article 1(1), ${ }^{214}$ and those embodied in international humanitarian law conventions are obligations erga omnes partes. ${ }^{215}$

Applying these rules to the closure of the Gaza Strip, it is clear that other states must react to Israeli violations of international humanitarian law and other applicable rules. This means that states and international organizations must not acknowledge as lawful the consequences of the Gaza Strip closure, but rather, they must exercise diligently any possible pressure while respecting international law, to persuade Israel to comply with its obligations.

The due diligence nature of the duty to ensure respect for international humanitarian law leaves states free to determine their course of action to persuade Israel. ${ }^{216} \mathrm{~A}$ willing state may decide to bring a claim against Israel before the UNSC, the UNGA, or a competent international court of tribunal with jurisdiction on the basis of the erga omnes / erga omnes character of the international law rules violated by Israel. ${ }^{217}$ However, the the erga omnes / erga omnes character of the rules violated by Israel cannot be used to circumvent the requirement of the consent of Israel to settle any dispute before an international court. ${ }^{218}$

If another state or international organization is willing to adopt countermeasures against Israel, it will be entitled to do so, since the closure of the Gaza Strip entails the serious violation of some obligations erga omnes and erga omnes partes. Under Articles 49-51 of the DARS, such a countermeasure must only aim at inducing Israeli compliance with international law, must be

2005, art. 5(c); Martin DAWIDOWICZ, Third-Party Countermeasures in International Law (Cambridge: Cambridge University Press, 2017)).

212 East Timor case, supra note 201 at para. 29; Wall opinion, supra note 24 at para. 155; Chagos opinion, supra note 81 at para. 180 .

213 Wall opinion, supra note 24 at para. 155.

214 UN Doc.CCPR/C/21/Rev.1/Add. 13 (2004), para. 2.

215 Henckaerts, supra note 203 at para. 119. See, also, extensively, LONGOBARDO, "The Contribution of International Humanitarian Law to the Development of the Law of International Responsibility Regarding Obligations Erga Omnes and Erga Omnes Partes" (2018) 23 Journal of Conflict and Security Law 433.

216 See, generally, Longobardo, supra note 93 at 56-63.

217 Questions Relating to the Obligation to Prosecute or Extradite (Belgium v. Senegal), [2012] I.C.J. Rep. 422 at paras. 68-70; Application of the Convention on the Prevention and Punishment of the Crime of Genocide (The Gambia v. Myanmar), Order of 23 January 2020, para. 41, online: ICJ <www.icj-cij.org/files/case-related/178/178-20200123-ORD01-00-EN.pdf>.

218 East Timor case, supra note 201 at para. 29; Armed Activities on the Territory of the Congo (New Application: 2002) (DRC v. Rwanda), [2006] I.C.J. Rep. 6 at para. 64. 
temporary and proportionate, and must not affect some rules of international law such as the ban on the use of armed force, obligations of a humanitarian character prohibiting reprisals, international human rights law, and other jus cogens rules.

It follows that countermeasures can be adopted against the illegal denial of access to relief operations in the Gaza Strip. In particular, two scenarios must be distinguished: 1) cases in which Israel denies relief from a state or an international organization, and 2) cases in which the relief is offered by an NGO. States and international organizations can adopt countermeasures when Israel does not accept their offers or when it negotiated without good faith the technical specificities of relief consignment in order to frustrate the purpose of the offers. On the other hand, since NGOs are not subjects of international law, NGOs cannot adopt countermeasures. Nevertheless, states and international organizations can undertake countermeasures in the interest of the population of the Gaza Strip even if they do not claim the violation of their right to deliver relief.

Accordingly, states and international organizations may dispatch goods to the Gaza Strip as relief action even without Israeli consent, as long as the other rules on relief consignment in occupied territory are respected (in particular, the humanitarian and impartial characters of the relief action). Such measures, which in principle violate Israeli rights, would be lawful because they would be adopted as a countermeasure, if they do not involve the use of armed force, which is always prohibited. ${ }^{219}$ Since providing relief without the consent of the occupying power may violate its territorial sovereignty, especially in the situation of the Gaza Strip where the goods may be transported through Israeli territory, this countermeasure is justified only in light of the seriousness of the Gaza Strip closure, which is a violation of international law that has lasted for more than a decade. ${ }^{220}$

Finally, it should be noted that the closure impacts on the Palestinian ability to fulfill some of its own international human rights law obligations. ${ }^{221}$ The fact that after 2014 Palestine has joined several international human rights law treaties means the Palestinian administration must respect, protect, and fulfill those rights in areas under its jurisdiction. Without entering the complex - and largely unexplored - debate of the partition of responsibilities between Israel and Palestine in light of

\footnotetext{
219 Akande and Gillard, supra note 192 at paras. 152-157.

220 Ibid., para. 156.

${ }^{221}$ On this topic, see, generally, Mutaz M. QAFISHEH, "The Ability of the Palestinian Legal System to Secure Adequate Standards of Living: Reform or the Failure of State Duty" (2013) 3 Asian Journal of International Law 393.
} 
the Oslo accords, ${ }^{222}$ suffice it to say, for the purposes of this article, that Palestine has claimed that the closure prevents it from implementing its international obligations. Indeed, in relation to the Convention on the Elimination of All Forms of Discrimination against Women, Palestine has argued that the "occupying forces prevent the relevant Palestinian parties from moving between the West Bank, including East Jerusalem, and the Gaza Strip in order to carry out their functions and reach women victims." 223 This situation may be relevant for the application of international human rights law to some people, which should be considered outside Palestinian jurisdiction, or to assess the diligence undertaken by the Palestinian administration in relation to the implementation of due diligence obligations. However, the lack of implementation of obligations upon Palestine, as a such, cannot be considered as an international wrongful act by Israel.

\section{CONCLUSIONS}

This article has demonstrated that the land closure of the Gaza Strip violates a number of rules international law. Although Israel has the right to limit the movement of persons and goods for security reasons, the relevant measures should be tailored on specific threats rather than being applied indiscriminately. In particular, the closure of the Gaza Strip should comply with rules embodied in international humanitarian law, international human rights law, the principle of self-determination of peoples, and the agreements concluded between Israel and the PLO.

Since the Gaza Strip is under Israeli occupation, and due to the principle of self-determination of peoples and the Israeli-PLO agreements, Israel must consider the Gaza Strip as a portion of a wider single territorial unit also comprising the West Bank. Accordingly, Israel must allow passages of persons between the two areas, following the agreed standards embodied in relevant Israeli-PLO agreements, which governs that passage still today.

Moreover, Palestinians enjoy freedom of movement under the ICCPR, to be interpreted and applied in light to international humanitarian law. Accordingly, Israel can restrict freedom of

\footnotetext{
${ }^{222}$ For one of the few comprehensive works on this topic, see Ralph WILDE, Expert Opinion on the Applicability of Human Rights Law to the Palestinian Territories with a specific Focus on the Respective Responsibilities of Israel, as the Extraterritorial State, and Palestine, as the Territorial State (Diakonia 2018), online: Diakonia <www.diakonia.se/globalassets/blocks-ihl-site/ihl-file-list/ihl--expert-opionions/the-applicability-of-human-rights-lawto-the-palestinian-territories-with-a-specific-focus-on>.

${ }^{223}$ UN Doc. CEDAW/C/PSE/1 (2017), para. 104. Other allegations pertain to areas temporary under Israeli jurisdiction, such as the settlements (ibid.: "There is also insufficient oversight by the occupation authorities of working conditions at facilities and workplaces that hire Palestinian workers-men and women-inside the Green Line and in the illegal settlements").
} 
movement only to restore and ensure public order, following the rules in force before the occupation or to fight epidemics. Any restrictions must be necessary, proportionate, temporary, reversible, and non-collective.

In relation to goods, the law of occupation demands that Israel allow the transit of food into the Gaza Strip that is necessary to comply with the ban on starvation, and to provide food, medical supplies, clothing, bedding, means of shelter, and other supplies essential to the survival of the civilian population. Furthermore, the law of occupation forbids Israel from barring access to relief consignment in the Gaza Strip if the relief is humanitarian in character and impartial.

In response to these violations of international law, Palestine as a state and/or the PLO, has the right to invoke Israeli responsibility, to demand cessation and reparation, and to adopt countermeasures. However, the lack of Israeli consent to settle the dispute judicially and the reality of occupation limit the Palestinian ability to react lawfully to Israeli violations. Nonetheless, since Israel is violating some jus cogens rules that produce erga omnes / erga omnes partes obligations, states not directly injured by Israeli violations and international organizations must not recognize as lawful the closure of the Gaza Strip and must cooperate to bring it to an end through measures permitted by international law. 